\title{
Litho-, bio-, and chemostratigraphy of the Middle Triassic carbonate succession in the North-Central Coast Region of Vietnam
}

Thuy Thi Nhu Ha ${ }^{1}$, Hideko Takayanagi ${ }^{1}$, Katsumi Ueno ${ }^{2}$, Yoshihiro Asahara ${ }^{3}$, Koshi Yamamoto ${ }^{3}$ and Yasufumi Iryu ${ }^{1 *}$ (D)

\begin{abstract}
Middle Triassic carbonates extend from the North-Central Coast region of Vietnam to northern Laos. We conducted sedimentological, paleontological, and geochemical analyses on the carbonates of the Hoang Mai Formation in Nghe An province, Vietnam. The carbonates consist of the following six lithostratigraphic units (from bottom to top): sandy limestone (unit 1), peloidal packstone with a microbialite interlayer (unit 2), peloidal packstone and oncoidal floatstone (unit 3), peloidal-bioclastic packstone (unit 4), peloidal packstone with variable quantities of bioclasts and microbialite (unit 5), and peloidal packstone with variable quantities of bioclasts (unit 6). The sandy nature of unit 1 and of three of the interlayers in unit 2 indicates a supply of terrigenous material during the early stages of formation of the Hoang Mai carbonate platform. The dominance of carbonates with a fine-grained matrix throughout the overlying succession implies a low-energy depositional environment. Common occurrences of dasycladalean algae in units 4-6 indicate a back-reef lagoon environment. A total of 24 foraminiferal taxa, including Citaella dinarica and C. deformata, were identified. These two age-diagnostic species occur in units $3-6$, suggesting that this interval is correlated with the Pelsonian and that the lower units (units 1-2) are potentially correlated with the Bithynian. Thus, the entire core section can be assigned to the middle Anisian (lower Middle Triassic). An assessment of the diagenetic alteration using geochemical parameters indicates that the carbonates of the studied succession have not retained their initial strontium $\left({ }^{87} \mathrm{Sr} /{ }^{86} \mathrm{Sr}\right)$ and oxygen $\left(\delta^{18} \mathrm{O}\right)$ isotope compositions. In contrast, the carbonates in the lower (units 1-2) and middle (units 2-5) intervals have retained their initial carbon isotope compositions $\left(\delta^{13} \mathrm{C}\right)$, making them suitable for $\mathrm{C}$ isotopic analyses. In the lower interval, we observe a slight $\delta^{13} \mathrm{C}$ enrichment, followed by a gradual $\delta^{13} \mathrm{C}$-depletion upwards into the middle interval. The observed trend in $\delta^{13} \mathrm{C}$ values from the Hoang Mai Formation can be correlated with similar trends reported from South China and Romania. Samples within the upper interval (units 5-6) of the Vietnamese $\delta^{13} \mathrm{C}$ profile are relatively $\delta^{13} \mathrm{C}$-depleted, which is likely the result of diagenetic overprinting.
\end{abstract}

Keywords: Chemostratigraphy, Foraminiferal biostratigraphy, Carbon isotope, Carbonate, Middle Triassic, Hoang Mai Formation, Vietnam

\footnotetext{
*Correspondence: yasufumi.iryu.d8@tohoku.ac.jp

'Department of Earth Science, Graduate School of Science, Tohoku

University, Sendai 980-8578, Japan

Full list of author information is available at the end of the article
} 

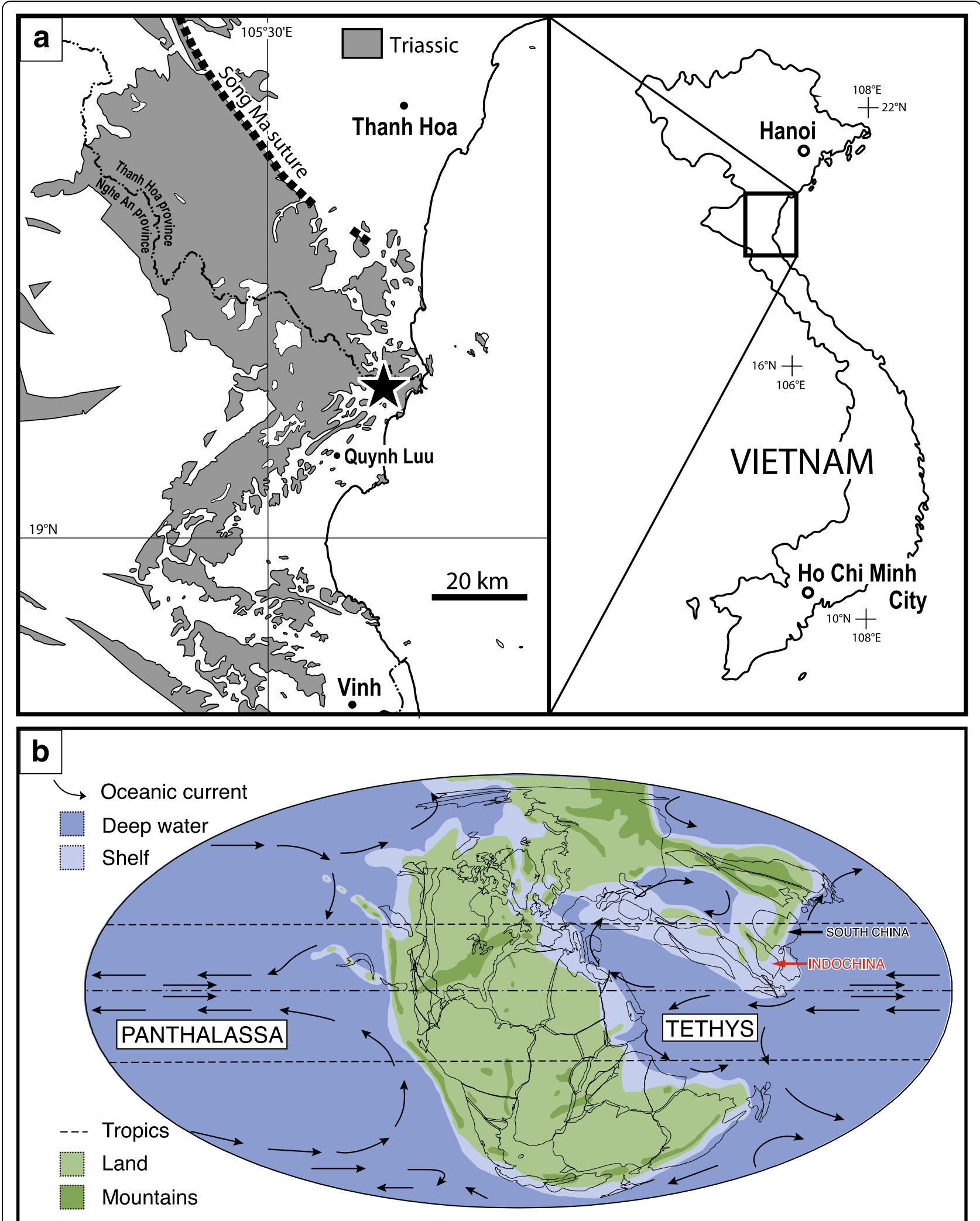

Fig. 1 Location of the study site. a Maps showing the study site. $\mathbf{b}$ Paleogeographic map of the Late Triassic (modified from Martindale et al. 2015) 


\section{Introduction}

Middle Triassic carbonate platforms extend westwards from the North-Central Coast region of Vietnam (Fig. 1a) to northern Laos (Dang 2006). The Trang An Landscape Complex carbonates, located near the southern margin of the Red River Delta, are designated a UNESCO World Natural Heritage site for their spectacular limestone karst peaks surrounded by steep, almost vertical cliffs. Large volumes of the limestone platforms have been mined for raw materials for cement. Several geological and paleontological studies have been conducted on the Middle Triassic carbonates in this region because of their importance as a tourist attraction and a mineral resource as well as for their scientific interest (Liem 1966; Geological Survey of Vietnam 1995; Shigeta et al. 2010; Thanh and Khuc 2011). However, many of those studies are written in Vietnamese (e.g., Vu and Trinh 1969; Vu et al. 1972; Liem 1973; Do 1983) and cannot easily be understood by international readers. The lithostratigraphy of the Triassic succession in the region is well established (e.g., Dang 2006). The Middle Triassic strata (including the carbonates) are widely distributed in Thanh Hoa and Nghe An provinces of the North-Central region of Vietnam as well as in northern Laos (e.g., Miyahigashi et al. 2017). Paleontological studies have been conducted on Middle Triassic ammonoids (Vu 1984, 1991; Shigeta et al. 2010), bivalves (Vu and Trinh 1969; Vu 1991), and foraminifera (Liem 1966; Ueno et al. 2019), including species that are age-diagnostic.

The Middle Triassic carbonates in this region are key to furthering our understanding of the geological development of the Indochina and South China blocks (e.g., Cai and Zhang 2009; Metcalfe 2011; Faure et al. 2014) and to reconstructing the paleobiogeography of the Paleo-Tethys (Miyahigashi et al. 2017). Here, we report the litho-, bio-, and chemostratigraphy of the Middle Triassic carbonate succession in Nghe An Province in the North-Central Coast region of Vietnam (Fig. 1a). This paper provides the first chemostratigraphic data for the Middle Triassic carbonates in this region.

Carbon isotope stratigraphy of marine carbonates provides records of past secular changes in the global carbon cycle and serves as a useful tool for stratigraphic correlation (Saltzman and Thomas 2012). However, the Middle Triassic carbon isotope stratigraphy is not well established compared with other geological periods, and reported $\delta^{13} \mathrm{C}$ profiles are not necessarily consistent with each other (Additional file 3: Figure S1). Consequently, here, we provide a new high-resolution Middle Triassic carbon isotope stratigraphy that is constrained by foraminiferal biostratigraphy.

\section{Geological setting}

The territory of Vietnam spans the South China and Indochina blocks. The boundary between them is considered to be the Red River Fault Zone (Tapponnier et al. 1990; Osanai et al. 2008) or the Song Ma Suture (Lepvrier et al. 2004, 2008; Metcalfe 2011, 2012; Udchachon et al. 2017), both of which strike NW-SE. The Indochina Block occupies the majority of Vietnam, with the South China Block being limited to the country's northern corner. Structurally, Vietnam is divided into five blocks: the Northeastern, Northwestern, Truongson, Kontum, and Nambo blocks (Nam 1995), with the last three blocks belonging to the Indochina Plate. The study site is near the northern border of the Truongson Block.

Triassic marine siliciclastics and associated carbonates in the Sam Nua Basin (Khuc 2000) extend along the northeastern margin of the Indochina Block from the Thanh Hoa and Nghe An provinces of Central Vietnam northwestward to northern Laos. The deposits are mainly Middle Triassic in age and are divided into three formations, which (from bottom to top) are the Dong Trau, Hoang Mai, and Quy Lang formations (Dang 2006). According to Thanh and Khuc (2011), the Dong Trau Formation is $1000-1500 \mathrm{~m}$ thick and consists mainly of conglomerate, sandstone, felsic tuff, and tuffaceous sandstone, interbedded with cherty shale, siltstone, sandy shale, marl, rhyolite, and dacite. The Hoang Mai Formation, resting conformably on the Dong Trau Formation, is $500 \mathrm{~m}$ thick and consists of basal marl and overlying bedded limestone (Khuc 2000). The limestone yields marine fossils such as bivalves (Costatoria curvirostris and C. proharpa; Thanh and Khuc 2011) and foraminifers (Liem 1966). However, the stratigraphic distribution of the foraminifers is not well defined. The Quy Lang Formation conformably overlies the Hoang Mai Formation and consists of 550-650 m-thick siliciclastics interbedded with carbonate (Thanh and Khuc 2011). This formation yields Balatonites sp., an age-diagnostic (middle Anisian) ammonoid, and abundant shallow-marine bivalves such as Costatoria goldfussi mansuyi and Trigonodus tonkinensis (Shigeta et al. 2010).

During the Anisian, the Paleo-Tethyan oceanic lithosphere was subducted beneath the Indochina Block, and a restricted (narrow) oceanic basin existed between the Indochina and South China blocks (Cai and Zhang 2009). The Anisian limestones extending along the northern margin of the Indochina Block in Vietnam and Laos formed in this restricted ocean basin (Fig. 1b).

\section{Methods/Experimental}

Drill cores (cores no. 1 and no. 4) were obtained from carbonate rocks of the Hoang Mai Formation in the Nghe An province, North-Central Coast region of Vietnam (Fig. 1). The cores were 130.0 and $160.0 \mathrm{~m}$ long (Figs. 2 and 3), and recovery was $100 \%$ and $99.3 \%$, respectively. The carbonates have a monoclinal structure, striking NESW to (less commonly) NNE-SSW and dipping $50^{\circ}-60^{\circ}$ 


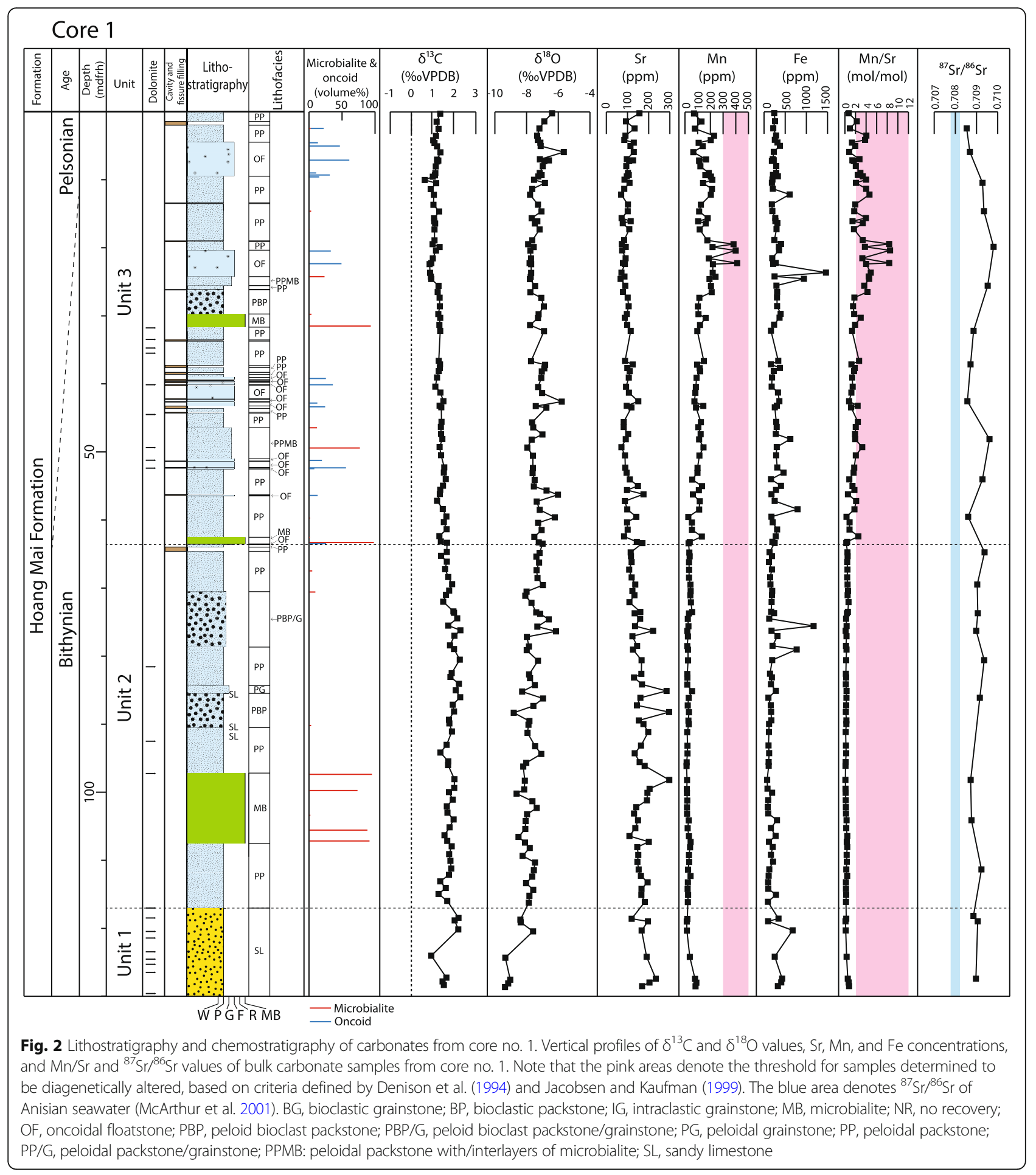

SE to ESE around the drill sites, and therefore, the core lengths were 1.5-2.0 times greater than the actual thickness of the beds ( 150-190 $\mathrm{m}$ thick).

A total of 290 bulk carbonate samples were collected from the two cores for geochemical analyses (Additional file 1: Table S1 and Additional file 2: Table S2). Efforts were made to avoid large bioclasts and microbial products (microbialites and oncoids), large cemented crystals, veins, stylolites, and pressure-solution seams. Additional samples were taken from veins and cements to compare their chemical and isotopic compositions with those of the bulk carbonate samples.

To identify and exclude diagenetically altered samples, mineral abundance and minor element (strontium (Sr), 


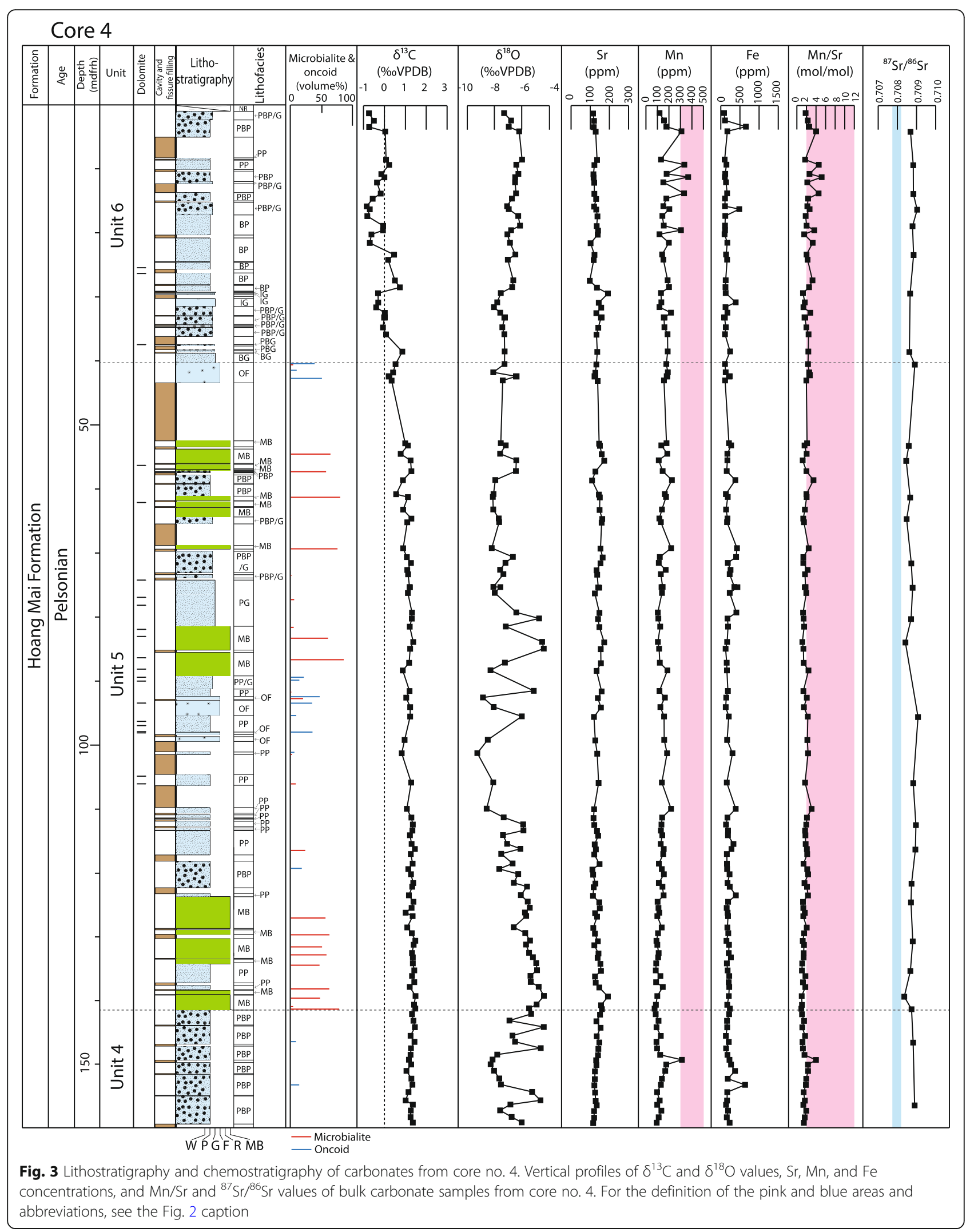


manganese $(\mathrm{Mn})$, and iron $(\mathrm{Fe})$ ) concentrations were determined. Mineral abundances were determined following Suzuki et al. (2006) with a Phillips X'pert-MPD PW3050 system at the Institute of Geology and Paleontology, Tohoku University, Japan (IGPS). Based on the results of the $\mathrm{X}$-ray diffraction (XRD) analysis, 42 samples were excluded from the subsequent minor element and isotope analyses because of their relatively high contents of dolomite (10-84 wt\%). Powdered samples $(0.3 \mathrm{mg})$ were dissolved in $\sim 4.5-10.0 \mathrm{~mL}$ of $2 \%$ nitric acid. The solutions were analyzed for concentrations of three minor elements ( $\mathrm{Sr}, \mathrm{Mn}$, and $\mathrm{Fe}$ ) using an Agilent $7700 \mathrm{x}$ inductively coupled plasma mass spectrometer at the Department of Earth and Environmental Sciences, Nagoya University, Japan. Minor element concentrations are expressed as $\operatorname{ppm}(=\mu \mathrm{g} / \mathrm{g})$. The external precision determined by replicate analyses of the laboratory standard was approximately $4.9 \%, 4.6 \%$, and $4.7 \%$ for the $\mathrm{Mn}, \mathrm{Fe}$, and $\mathrm{Sr}$ concentrations, respectively.

To provide chronological constraints on the studied carbonate succession, strontium isotope ratios $\left({ }^{87} \mathrm{Sr} /{ }^{86} \mathrm{Sr}\right)$ and foraminiferal assemblages were analyzed for 53 and 68 samples, respectively. The ${ }^{87} \mathrm{Sr} /{ }^{86} \mathrm{Sr}$ was measured with a VG Sector 54-30 thermal ionization mass spectrometer at the Department of Earth and Environmental Sciences, Nagoya University, following protocols by Asahara et al. (1999, 2006) and Suzuki et al. (2012). Replicate analyses of the National Institute of Standards and Technology (NIST) Standard Reference Material 987 during this study gave a value of $0.710254 \pm 0.000008(1 \sigma, n=9)$. All measurements were normalized to 0.710248 (McArthur et al. 2001).

To establish chemostratigraphy, the carbon $\left(\delta^{13} \mathrm{C}\right)$ and oxygen $\left(\delta^{18} \mathrm{O}\right)$ isotope ratios of 248 samples were measured with a Thermo Fisher Delta V isotope ratio mass spectrometer coupled to a ThermoQuest Kiel-III automated carbonate device, at IGPS. The samples ( $0.1 \mathrm{mg}$ ) were reacted with $100 \%$ phosphoric acid at $72{ }^{\circ} \mathrm{C}$. The isotope ratios were expressed in conventional $(\delta \%)$ notation and calibrated to the NBS-19 international standard, relative to Vienna Pee Dee Belemnite (VPDB). The external precisions $(1 \sigma)$ for the carbon and oxygen isotope analyses based on replicate measurements $(n=71)$ of the laboratory reference materials JCp- 1 were $0.02 \%$ and $0.03 \%$, respectively.

The $\delta^{18} \mathrm{O}$ values for $\mathrm{Mg}$-calcite are higher than those for pure calcite (e.g., Tarutani et al. 1969). If a fractionation correction for $\mathrm{Mg}$-calcite relative to pure calcite was applied $\left(0.06 \%\right.$ per $\mathrm{mol} \% \mathrm{MgCO}_{3}$, according to Tarutani et al. 1969; $0.17 \%$ per $\mathrm{mol} \% \mathrm{MgCO}_{3}$, according to Jiménez-López et al. 2004), the Mg effect on the $\delta^{18} \mathrm{O}$ values is negligible because the $\mathrm{Mg}$ contents of the analyzed samples were $<0.1 \mathrm{~mol} \% \mathrm{MgCO}$.

\section{Results}

Core no. 1

Lithostratigraphy

The studied carbonate succession (Fig. 2) represents a continuous depositional record, with no observed erosional surfaces that indicate a hiatus. Dissolution cavities are common in the upper half of the core and are filled with various-sized breccias derived from the surrounding limestone and/or laminated lime mud. Dissolution vugs are common and are filled with sparry calcite.

The interval from the base of the core (130.0 mdfrh, meters depth from the reference horizon (= the ground surface when the drilling was conducted)) to $117.0 \mathrm{mdfrh}$ consists mostly of sandy limestone with peloids (Fig. 4a). The limestone is characteristically grayish-black to black in color, likely due to small (mud-sized) grains of quartz, as indicated by XRD analyses and thin-section observations. Peloids are irregularly shaped with obscure outlines and are coarse sand sized or smaller. Bioclasts are rare but include ostracods, foraminifers, and echinoids. Bioturbation is common. Intergranular pore spaces are filled with micrite, which is partly replaced with sparry calcite. Dolomite content is high, reaching $70 \mathrm{wt} \%$ in several horizons in this lower interval of the core (130.0-117.0 mdfrh).

The core interval 117.0-63.5 mdfrh, which is the middle interval of the core, is dominated by peloidal packstone (Fig. 4c). Peloids are irregular or (rarely) subrounded and mostly in the medium to very coarse sand size fractions. Bioclasts, including foraminifers, ostracods, bivalves (dominated by thin-shelled bivalves), gastropods, and echinoids, are rare and possess micrite envelopes. Intergranular pore space is filled with micrite and some sparry calcite. Bioturbation is common. Borings are filled with peloids, with a grainstone texture. A layer of microbialite in a matrix of peloidal packstone, at 108.0-97.2 mdfrh, is composed of loosely overlapped micritic laminae, binding peloids derived from the peloidal packstone matrix (Fig. 4c). The middle interval contains three interlayers of sandy limestone that are lithologically similar to those in the lower interval (130.0-117.0 mdfrh).

The interval from 63.5 mdfrh to the top of the core consists of peloidal packstone and oncoidal floatstone. The peloidal packstone is similar to that in the interval below (117.0-63.5 mdfrh). Oncoids are rounded to subrounded, pebble sized or smaller, and composed of loosely overlapping, irregularly undulated micritic envelopes (Fig. 4d). The nuclei of some oncoids are bioclasts. Small oncoids are commonly aggregated to form larger oncoids. The matrix of the oncoidal floatstone is a peloidal packstone to grainstone. Bioclasts have micrite envelopes regardless of their lithology. Intergranular pore space in the oncoidal floatstone and the peloidal packstone is filled with micrite and some sparry calcite. Dolomite is common in the lower half of this interval 

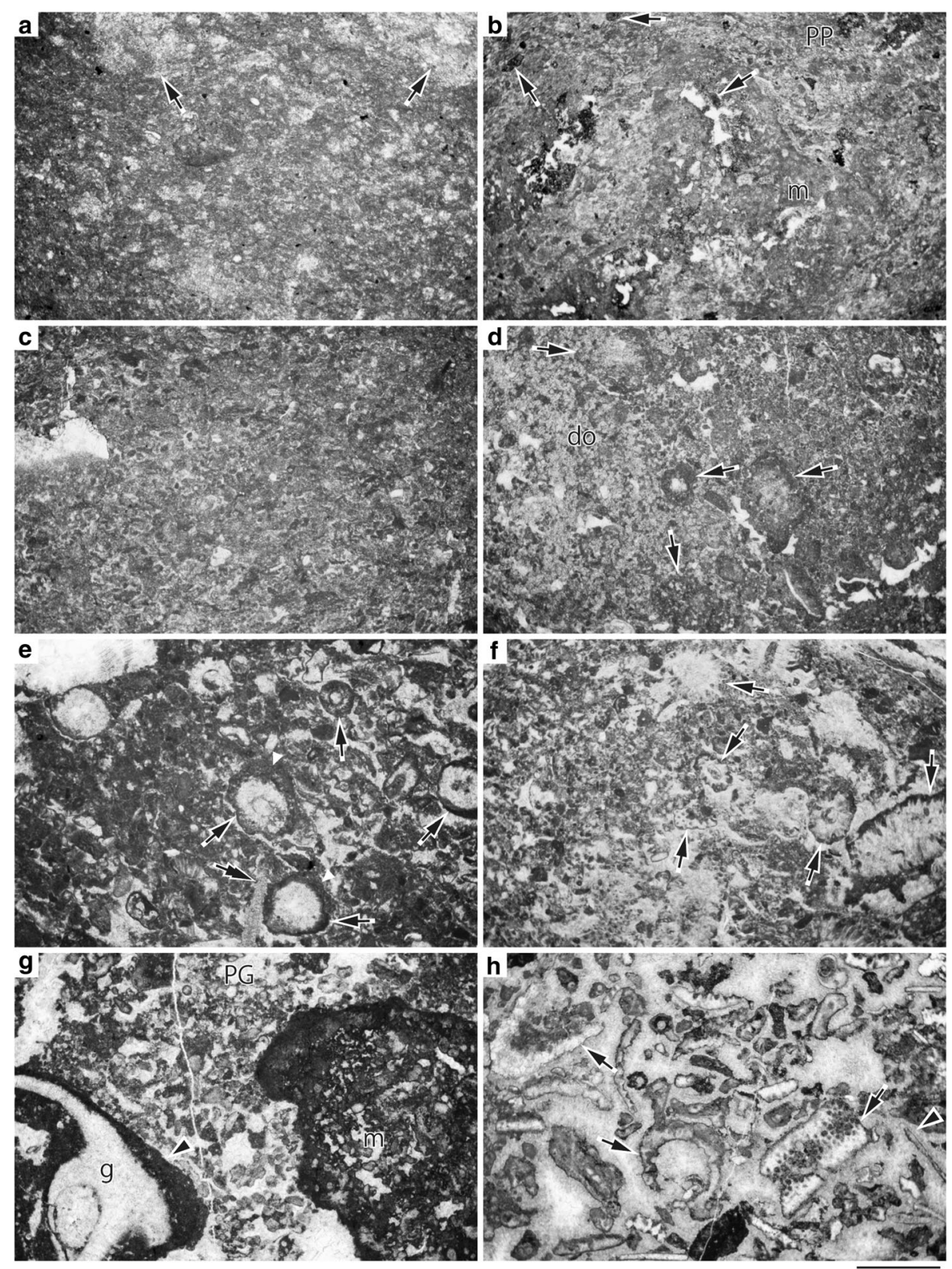

Fig. 4 Microfacies of the studied carbonates. a Sandy limestone with peloids, unit 1, 117.0 mdfrh in core no. 1, sample 1-140. Note bioturbation (arrows). b Microbialites (m) with a matrix of peloidal packstone (pp), unit 2, 105.5 mdfrh in core no. 1, sample 1-128. Note poorly laminated micritic mass binding peloids (arrows) derived from the peloidal packstone matrix. c Peloidal packstone, unit 2,67.4 mdfrh in core no. 1, sample 1-86. d Dolomitized oncoidal floatstone, unit 3, 51.2 mdfrh in core no. 1, sample 1-67. Note oncoids (arrows) and dolomite rhombs (do). e Peloid bioclast packstone, unit 4, 156.5 mdfrh in core no. 4, sample 4-139. Note bioclasts of dasycladalean algae (arrows) and echinoid (double arrowhead) and thick micrite envelopes (white arrowheads). f Peloid bioclast packstone rich in dasycladalean algae (arrows), unit 5, 140.8 mdfrh in core no. 4, sample 4-123. g Microbialite (m) with a matrix of peloidal grainstone (PG), unit 5, 98.3 mdfrh in core no. 4, sample 4-86. Note a gastropod (g) with a thick micrite envelope (arrowhead) $\mathbf{h}$ Bioclastic grainstone, unit 6, 38.5 mdfrh, sample 4-35, in core no. 4. Note bioclasts of dasycladalean algae (arrows) and a thin-shelled bivalve (arrowhead). Scale bar, $1 \mathrm{~mm}$ 
and exceeds $10 \mathrm{wt} \%$ in nine horizons, reaching a maximum content of $59 \mathrm{wt} \%$ (Fig. 4d).

\section{Minor element concentrations}

The $\mathrm{Sr}$ concentrations in the core samples range between 50 and $200 \mathrm{ppm}$, with seven high-concentration outliers (Fig. 2; Additional file 1: Table S1). Sr concentrations gradually decrease upwards from the base to $53.2 \mathrm{mdfrh}$, with the high-concentration outliers being found at 98.5-76.5 mdfrh. From 53.2 mdfrh to the top of the core, $\mathrm{Sr}$ concentrations fluctuate at $100 \mathrm{ppm}$ (mean $=98 \mathrm{ppm})$.

Mn concentrations are less than $250 \mathrm{ppm}$, except for three high-concentration outliers. Near the base of the core (128.8-120.6 mdfrh), Mn concentrations decrease upwards from 83 to $15 \mathrm{ppm}$, followed by an interval of low Mn concentrations (10-60 ppm) at 120.6-63.4 mdfrh. Above this interval, Mn concentrations fluctuate, showing a slight increase upwards between $\sim 50$ and $\sim 100 \mathrm{ppm}$ at 63.4-27.4 mdfrh. Mn concentrations then increase to 210 ppm at $26.5 \mathrm{mdfrh}$. From here to the top of the core, concentrations show relatively large amplitude variability but broadly decrease upwards to $71 \mathrm{ppm}$, with three highconcentration outliers at 22.3-19.5 mdfrh.

Fe concentrations vary mostly between 70 and $400 \mathrm{ppm}$. Fe concentrations show a broad decrease upwards from 327 to $74 \mathrm{ppm}$ (with one high-concentration outlier) in the lowermost interval from the base to $98.5 \mathrm{mdfrh}$ and then increase to $\sim 200 \mathrm{ppm}$ (with two high-concentration outliers) in the overlying interval up to $64.9 \mathrm{mdfrh}$. From this horizon to the top of the core, Fe concentrations range from 200 to $400 \mathrm{ppm}$, except for five highconcentration (>600 ppm) outliers.

\section{Carbon, oxygen, and strontium isotope stratigraphies}

The $\delta^{13} \mathrm{C}$ values in the core range from 0.60 to 2.28\%o (Fig. 2; Additional file 1: Table S1). In the lowest interval of the core (from the base to $115.4 \mathrm{mdfrh}$ ), the $\delta^{13} \mathrm{C}$ values vary quite widely, from 0.91 to $2.19 \%$. Above this (from 115.4 to $76.5 \mathrm{mdfrh}$ ), the $\delta^{13} \mathrm{C}$ values increase upwards from 1.25 to $2.28 \%$. The $\delta^{13} \mathrm{C}$ values in the uppermost part of the core range between 0.60 and $2.28 \%$ and decrease upwards to reach core-top values of $1.13-1.33 \%$.

The $\delta^{18} \mathrm{O}$ values range from -9.36 to $-5.65 \%$. The $\delta^{18} \mathrm{O}$ values increase from -9.36 to $-7.59 \%$ in the lowest interval of the core (from the base to $120.6 \mathrm{mdfrh}$ ). Above this interval, the $\delta^{18} \mathrm{O}$ values range mostly between -8.5 and $-6.0 \%$ and gradually increase to the top of the core.

The ${ }^{87} \mathrm{Sr} /{ }^{86} \mathrm{Sr}$ values ranges from 0.70853 to 0.70981 (Fig. 2; Additional file 1: Table S1). Ratios vary from 0.70872 to 0.70938 in the interval of $127.7-64.9$ mdfrh and from 0.70853 to 0.70981 in the interval of $59.7-2.4$ mdfrh.

\section{Biostratigraphy}

Foraminifers are rare in the lower interval of core no. 1 (from the base up to $\sim 64 \mathrm{mdfrh}$ ), but numerous in the upper interval of the core. Twelve taxa are identified in 25 samples (Table 1, Fig. 5). In the lower part, foraminiferal fauna is simple in composition and entirely represented by the genera Hemigordiellina and Endotriadella, indeterminable duostominids (probably of the genera Duostomina and/or Diplotremina) and nodosarrids (Fig. 5a, e, x, and y). These are all long-ranging taxa and are therefore not very useful for detailed biochronologic assessment. The scarcity of foraminifers in this interval is probably due to the dominance of sandy (detrital) limestone facies with some finegrained siliciclastic material, which is not conducive for hosting shallow-water dwelling benthic forms. Foraminiferal recovery is poor also at 55-32 mdfrh in the upper interval, which may be related to the development of common dolomite levels in this interval (Fig. 2).

Endotriadella wirzi (Fig. 5s), whose first appearance datum is recorded within the Pelsonian (late middle Anisian) according to Salaj et al. (1983), first occurs at 63.51 mdfrh. This species has a longer range in the Nanpanjiang Basin of South China, from the latest Olenekian to the early Carnian (Lehrmann et al. 2015), but is usually more characteristic of the middle to late Anisian and Ladinian (Salaj et al. 1983; Oraveczné Scheffer 1987). Endotriadella pentacamerata (Fig. 5r), whose first appearance datum is recorded within the Pelsonian (late middle Anisian) in the type area of this species (Salaj et al. 1983), first occurs in this core at 25.60 mdfrh. These two Endotriadella species are also found in core no. 4 . In the uppermost part of core no. 1 (at 9.28 and $7.10 \mathrm{mdfrh}$ ), three age-diagnostic species, namely, Citaella dinarica (Fig. 5l-p), C.? deformata (Fig. 5tv), and Endotriada tyrrhenica (Fig. 5k), appear at virtually the same level. Of these, $C$. dinarica is well known as a typical Anisian index species (e.g., Salaj et al. 1983; Rettori 1995) with a range in the early to middle Anisian (Ueno et al. 2018). Citaella? deformata, which has rather diverse morphology, is now considered a reliable indicator of the Pelsonian (Ueno et al. 2018). Endotriada tyrrhenica is generally reported from the upper part of the Anisian (broadly corresponding to the Pelsonian and Illyrian) (Lehrmann et al. 2015). Although identification was qualified, Pilammina cf. densa (Fig. 5c) is found in sample 1-3 (at $2.43 \mathrm{mdfrh}$ ) from the topmost part of core no. 1. Pilammina densa characterizes the Pelsonian and Illyrian in large areas of Eurasia (e.g., Salaj et al. 1983; Velledits et al. 2011; Miyahigashi et al. 2017).

Based on the foraminiferal biostratigraphy, Ueno et al. (2019) conclude that the uppermost part of core no. 1 (above $9.28 \mathrm{mdfrh}$ ) is Pelsonian (late middle Anisian), as is probably the entire upper interval of the core (above 63.54 mdfrh). This further suggests that the lower half of core no. 1, where foraminiferal recovery is poor, is 


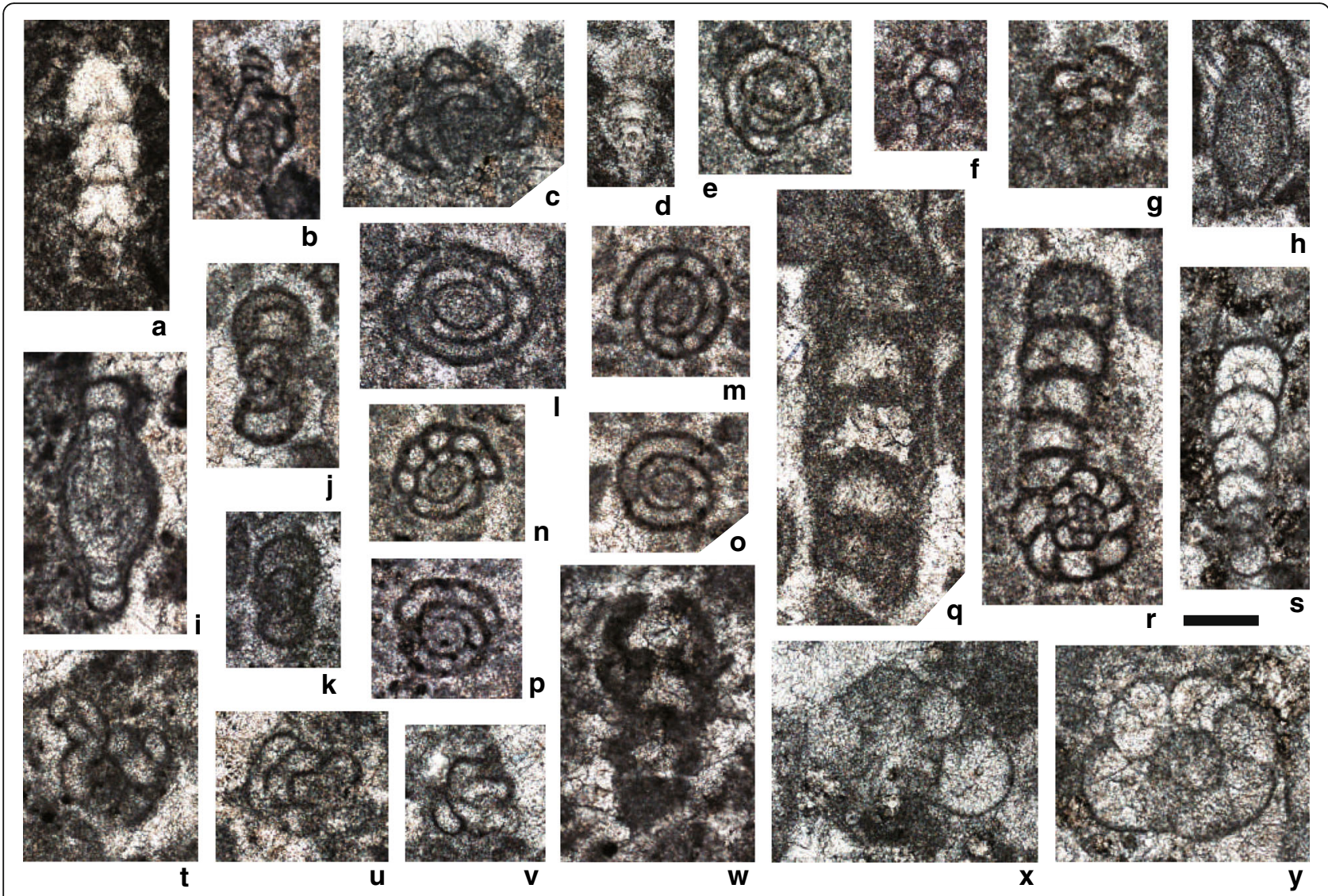

Fig. 5 Photomicrographs of important foraminifers obtained from the studied cores. a Indeterminable nodosariid, sample 4-83; b Pilamminella grandis (Salaj in Salaj et al. 1967), sample 4-34; c Pilammina cf. densa Pantić 1964, sample 1-3; d Austrocolomia sp., sample 4-136; e Hemigordiellina sp., sample 4-83; f Valvulina cf. azzouzi Salaj 1977, sample 4-79; $\mathbf{g}$ Gaudryina sp., sample 4-102; h Indeterminable involutinid (Aulotortus?), sample 4-139; i Triadodiscus cf. praecursor (Gaździcki in Gaździcki et al. 1975), sample 4-129; j Endoteba sp. A., sample 4-117; k Endotriada tyrrhenica Vachard et al. 1994, sample 1-14; I-p Citaella dinarica (Kochansky-Devidé and Pantić 1966), I sample 4-29, $\mathbf{m}-\mathbf{p}$ sample 4-55; q Earlandinita sp., sample 4-16; $\mathbf{r}$ Endotriadella pentacamerata (Salaj in Salaj et al. 1967), sample 4-83; s Endotriadella wirzi (Koehn-Zaninetti 1969), sample 1-82; t-v Citaella? deformata (Salaj in Salaj et al. 1967), t sample 4-55, u sample 4-29, v sample 4-139; w Ammobaculites? sp., sample 4-9; $\mathbf{x}$ and $\mathbf{y}$ indeterminable duostominids (probably Duostomina or Diplotremina), $\mathbf{x}$ sample 114, y sample 1-7. Scale bar, $200 \mu \mathrm{m}$ (applicable to all specimens)

potentially pre-Pelsonian in age and may possibly be Bithynian (early middle Anisian). This assessment also concurs with stratigraphic evidence that the conformably underlying Dong Trau Formation is correlated to the early to middle Anisian (Thanh and Khuc 2011). Thus, the Hoang Mai Formation in core no. 1 is correlated to the middle Anisian (early Middle Triassic).

\section{Core no. 4}

\section{Lithostratigraphy}

The studied carbonate succession has no observed hiatuses and represents a continuous depositional record (Fig. 3). Dissolution cavities filled with various-sized breccias and/or laminated lime mud are common in the upper core down to $110 \mathrm{mdfrh}$. Dissolution vugs are common and are filled with sparry calcite.
The lowest interval of the core, from the base (160.0 mdfrh) to $141.9 \mathrm{mdfrh}$, is composed mainly of peloid bioclast packstone (Fig. 4e). The packstone has abundant irregularly shaped peloids of up to coarse sand size. Bioclasts, with micrite envelopes, are common, including dasycladalean algae and, less commonly, foraminifers, ostracods, gastropods, bivalves, and brachiopods. Many of the bioclasts, however, are poorly preserved, and could not be taxonomically identified. Intergranular pore space is filled with micrite and some sparry cement.

The core interval from 141.9 to 40.4 mdfrh consists of peloidal packstone with variable amounts of bioclasts (Fig. 4f) and microbialite (Fig. 4g) and is associated with oncoidal floatstone. The peloidal packstone and related types (e.g., peloid bioclast packstone, peloidal grainstone) have similar components to those of the peloid bioclast packstone in the lowest core interval (160.0-135.0 mdfrh). 


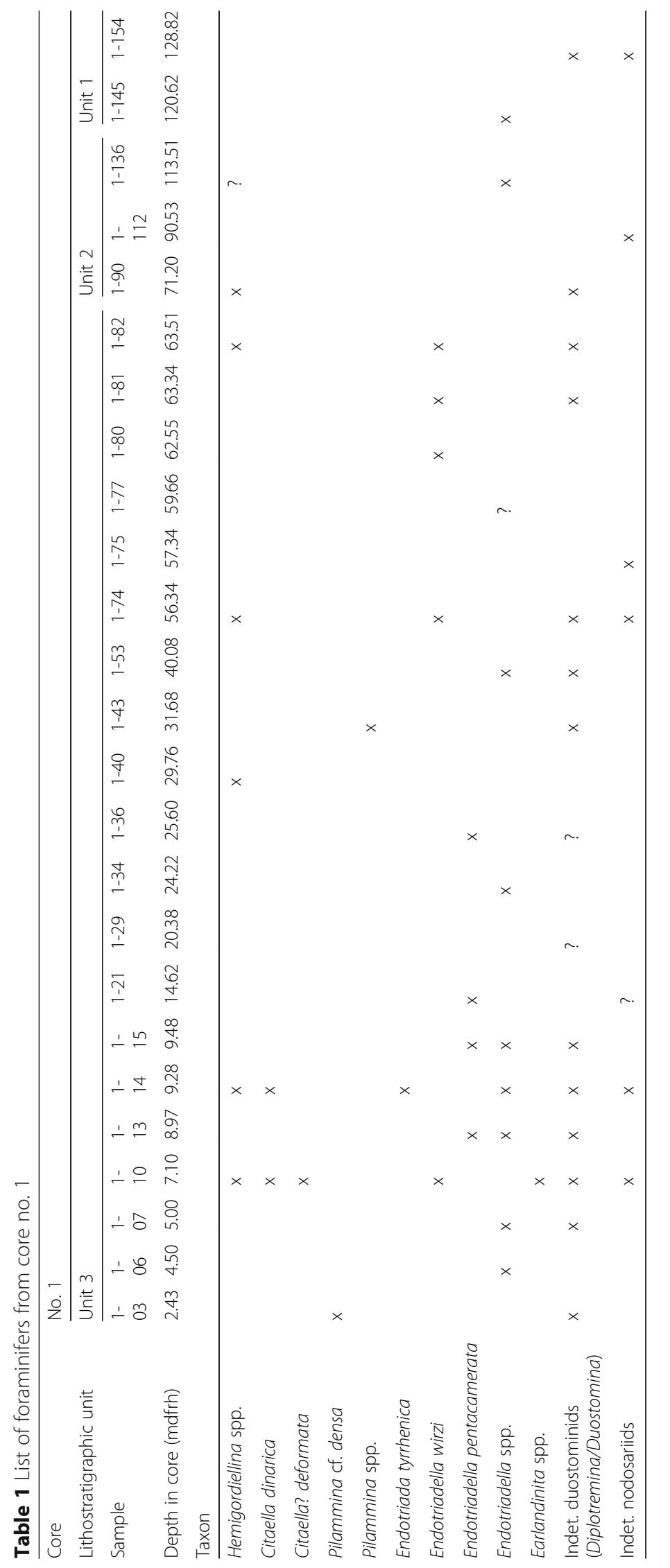


The microbialite is composed of an irregular framework of laminated and clotted micrite, in which irregularly shaped peloids and bioclasts are loosely bound. Microbial filaments are commonly preserved and measure 40$90 \mu \mathrm{m}$ in diameter. The bioclasts all have micrite envelopes and include dasycladalean algae, small foraminifers, and, to a lesser extent, gastropods, bivalves, and echinoderms. Intergranular pore space is filled with micrite and some sparry cement. Dolomite contents exceed $10 \mathrm{wt} \%$ in 18 horizons and reach a maximum value of $84 \mathrm{wt} \%$.

The interval from 40.4 mdfrh to the core top is composed mainly of peloidal packstone associated with grainstone, both with variable amounts of bioclasts. The peloids are irregularly shaped and coarse sand-sized or smaller. Bioclasts are common to abundant and are derived from dasycladalean algae, foraminifers, gastropods, and bivalves (Fig. 4h). Many bioclasts, however, could not be taxonomically identified because of poor preservation. The bioclasts all have micrite envelopes of varying thickness (the bioclasts with thick micrite envelopes can be classed as cortoids). Intergranular pore space is filled with micrite and some sparry cement.

\section{Minor element concentrations}

The $\mathrm{Sr}$ concentrations in the core samples lie mainly between 100 to $170 \mathrm{ppm}$, with four higher outliers and one lower outlier (Fig. 3; Additional file 2: Table S2). The Sr concentrations vary irregularly and have no systematic trend with depth.

The Mn concentrations in the lowest interval of the core (from the base to $88.5 \mathrm{mdfrh}$ ) range from 70 to $190 \mathrm{ppm}$, with one outlier, and increase slightly upwards. In the interval above (87.3-79.4 mdfrh), Mn concentrations fall in a narrow range from 100 to $122 \mathrm{ppm}$. Mn concentrations are more variable in the interval above (76.4-20.2 mdfrh) and range between 101 and $226 \mathrm{ppm}$. Mn concentrations are the most variable in the uppermost interval, from 19.5 mdfrh to the core top (116 to $370 \mathrm{ppm}$ ).

The Fe concentrations range mostly from 100 to 250 ppm, with a random distribution of higher concentration outliers. The Fe concentration profile, excluding the outliers, decreases slightly upwards.

\section{Carbon, oxygen, and strontium isotope stratigraphies}

The $\delta^{13} \mathrm{C}$ values range from -0.89 to $1.48 \%$ (Fig. 3; Additional file 2: Table S2). From the base of the core to $52.9 \mathrm{mdfrh}$, the $\delta^{13} \mathrm{C}$ values fall in a narrow range of $0.54-1.48 \%$. In the upper core interval (41.80 mdfrh), $\delta^{13} \mathrm{C}$ values broadly decrease upwards to $0.78 \%$.

The $\delta^{18} \mathrm{O}$ values range from -9.27 to $-4.42 \%$. $\delta^{18} \mathrm{O}$ values in the lowest interval of the core, from the base to 147.7 mdfrh, are highly variable, ranging between -7.82 and $-4.65 \%$. From the top of this interval to $101.5 \mathrm{mdfrh}$, the $\delta^{18} \mathrm{O}$ values decrease to $-9.27 \%$ and then increase to $-4.77 \%$ from 101.5 to 80.4 mdfrh. The $\delta^{18} \mathrm{O}$ profile then increases upwards from -8.00 to $-6.01 \%$ from 76.4 to $8.5 \mathrm{mdfrh}$ and abruptly decreases in the uppermost $8.5 \mathrm{~m}$ to reach a value of $-7.32 \%$ at the top of the core.

The ${ }^{87} \mathrm{Sr} /{ }^{86} \mathrm{Sr}$ values ranges between 0.70833 and 0.70906, showing no systematic trend (Fig. 3; Additional file 2: Table S2).

\section{Biostratigraphy}

Foraminifers are more abundant and diverse in core no. 4 than in core no. 1. A total of 23 taxa of foraminifers were identified from 43 samples (Table 2; Fig. 5). The higher foraminiferal abundance compared with core no. 1 corresponds to the more common shallow-marine peloidal-bioclastic microfacies in core no. 4, which would have been a more suitable habitat for benthic foraminifers. Most foraminifers found in core no. 1, especially those from the uppermost interval (except Pilammina cf. densa), are also present in core no. 4.

Citaella dinarica and C.? deformata are diagnostic throughout core no. 4, as in the uppermost $10 \mathrm{~m}$ in core no. 1. Endotriadella wirzi and E. pentacamerata, which also occur in the upper interval of core no. 1, are found from near the base up to $\sim 65 \mathrm{mdfrh}$. Endotriada tyrrhenica is common in the middle part of core no. 4 , with the same upper limit as Endotriadella wirzi at $64.67 \mathrm{mdfrh}$. There are also single occurrences of biostratigraphically useful foraminifers, including Pilammina grandis (Fig. 5b) in sample 4-34 (at $37.66 \mathrm{mdfrh}$ ), which has been reported from various areas in Eurasia and is restricted to the Anisian (Gaździcki et al. 1975; Salaj et al. 1983; Velledits et al. 2011; Lehrmann et al. 2015; Miyahigashi et al. 2017). Triadodiscus cf. praecursor (Fig. 5i) is putatively identified in sample 4-129 (at $146.67 \mathrm{mdfrh}$ ). This species was originally described from the Pelsonian of the Polish Muschelkalk (Gaździcki et al. 1975). Valvulina azzouzi, which is also putatively identified in the middle of core no. 4 (sample 4-79 at 91.68 mdfrh), is known to appear first in the middle Anisian in the West Carpathian Mountains, where extensive biostratigraphic research on Triassic foraminifers has been conducted (Salaj et al. 1983).

Ueno et al. (2019) classified core no. 4 as Pelsonian (late middle Anisian), based mainly on the co-occurrence of $C$. dinarica and C.? deformata. This core has a similar faunal composition to that of the upper part of core no. 1, implying stratigraphic continuity between these successions in the two cores. In core no. 4 , the age-diagnostic $C$. dinarica is present only up to $19.49 \mathrm{mdfrh}$. In view of the chemostratigraphic uniformity in the uppermost part of the core (Fig. 3), and the observation that there are no erosional surfaces, it is highly likely that the entire core is Pelsonian in age. 


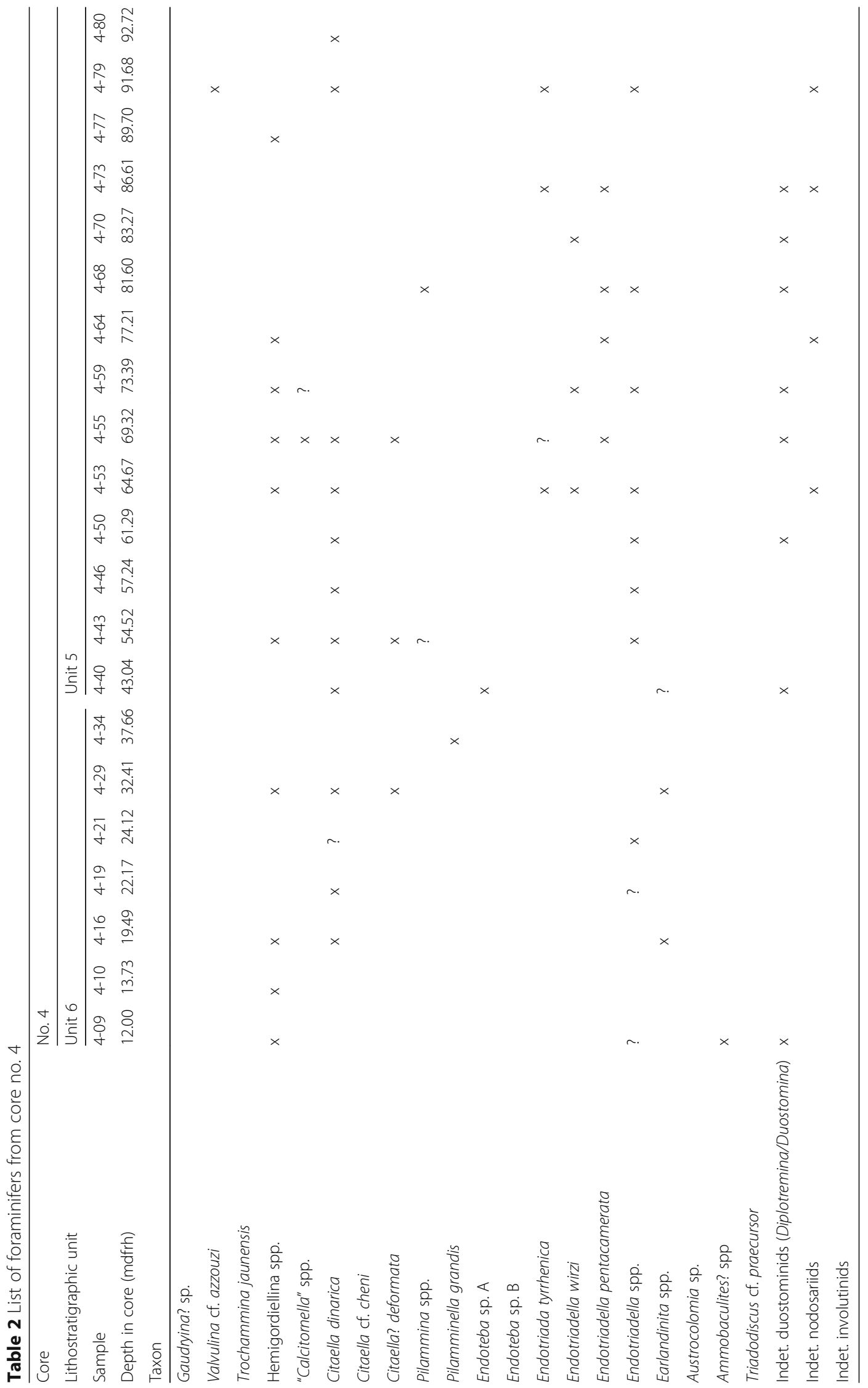


Ha et al. Progress in Earth and Planetary Science $\quad$ (2019) 6:47

Page 13 of 21

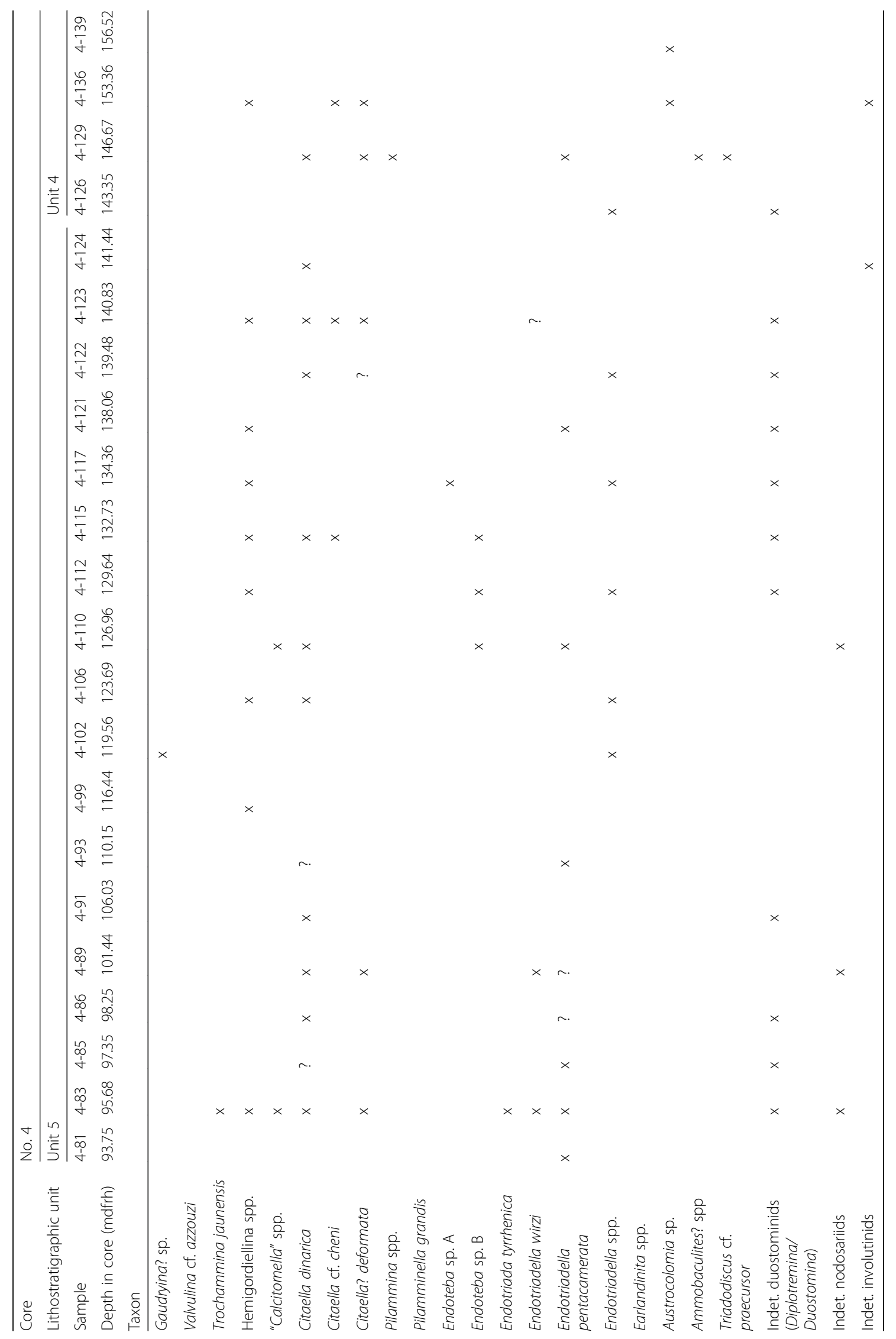




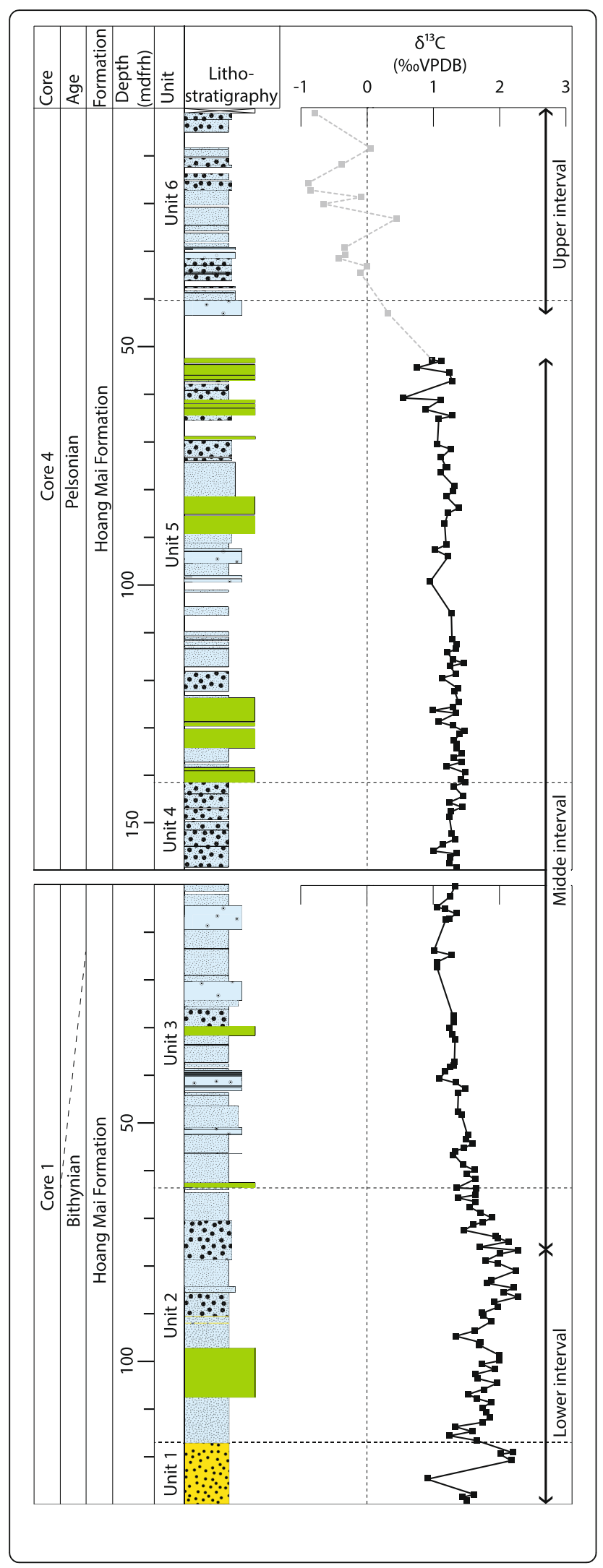

Fig. 6 Composite lithostratigraphy and carbon isotope stratigraphy of bulk carbonate samples from this study (cores no. 1 and 4). The $\delta^{13} \mathrm{C}$ values presented are those of samples that are not diagenetically altered, as inferred from trace element ( $\mathrm{Mn}$ and $\mathrm{Sr}$ ) criteria as defined in the subsection "Isotope and minor element profiles" of the main text. Using these criteria, 67 samples were removed from consideration (Additional file 1: Table S1 and Additional file 2: Table S2). The marked decrease observed in the $\delta^{13} \mathrm{C}$ profile in the upper interval (uppermost unit 5 and unit 6; shown in gray) is likely due to diagenetic overprinting (meteoric diagenesis). For the definition of the pink and blue areas and abbreviations, see the Fig. 2 caption

\section{Discussion}

Carbonate succession in the study area and its sedimentary environment

The rock units surrounding the drill sites have a monoclinal structure, striking NE-SW (in some cases up to NNE-SSW) and dipping $50^{\circ}-60^{\circ} \mathrm{SE}$ to ESE. Core no. 1 was drilled $\sim 800 \mathrm{~m}$ north of core no. 4 . Normal faults occur between the two drill sites. Based on the spatial configuration of the sandy limestone (unit 1) around the drill sites, it is expected that unit 1 occurs $\sim 115 \mathrm{~m}$ below the base of core no. 4. As the uppermost horizon of unit 1 in core no. 1 is located at $117.0 \mathrm{mdfrh}$, the base of core no. 4 is at a similar stratigraphic level to the top of core no. 1. This interpretation is supported by the $\delta^{13} \mathrm{C}$ data, where $\delta^{13} \mathrm{C}$ values in the lowest interval of core no. 4 (160-155 mdfrh, 1.0-1.4\%o; Fig. 3, Additional file 2: Table S2) predominately fall into the same narrow range as those in the uppermost part of core no. 1 (0-5 mdfrh, 1.0-1.3\%o; Fig. 2, Additional file 1: Table S1). Foraminiferal biostratigraphy provides further support for the correlation of the two cores. Nevertheless, the lithological differences between core no. 1 and core no. 4 (i.e., peloid bioclast packstone vs. oncoidal floatstone, respectively) indicate that they do not overlap in time. Consequently, we interpret the base of core no. 4 as stratigraphically just a few meters above the top of core no. 1 (Fig. 6). The total thickness of the studied succession is thus estimated to be 150-190 m.

The carbonate succession is composed of six lithostratigraphic units that are numbered sequentially from the base (unit 1) to the top (unit 6). Unit 1 (130.0-117.0 mdfrh in core 1 ) is composed mainly of sandy limestone; unit 2 (117.0-63.5 mdfrh in core 1) consists chiefly of peloidal packstone with a microbialite interlayer; unit 3 (63.50 mdfrh in core 1) is composed mainly of peloidal packstone and oncoidal floatstone; unit 4 (160.0-141.9 mdfrh in core 4) is mainly peloid bioclast packstone; unit 5 (141.940.4 mdfrh in core 4) is a peloidal packstone with a variable quantity of bioclasts and microbialite; and unit 6 (40.40 mdfrh in core 4) is dominated by peloidal packstone with a variable abundance of bioclasts. The sandy nature of unit 1 and of three interlayers in unit 2, along with dark rock 
color of these units, indicates a supply of terrigenous material in the early stages of deposition on the platform where the Hoang Mai Formation carbonates accumulated. The dominance of carbonates with a fine-grained matrix throughout the remaining units suggests deposition in a low-energy subaqueous environment.

The occurrence of oncoids in the peloidal packstone matrix from units 3 and 5 does not necessarily indicate a high-energy depositional environment in which frequent overturning occurred, as the fine carbonate fractions in such settings are swept away. It is known that the overturning of algal nodules is not limited to water motion but can also be driven by biotic activity on the seafloor (Prager and Ginsburg 1989; Matsuda and Iryu 2011). At present, the overturning mechanism of oncoids in the Hoang Mai Formation is not clear without further taphonomical study. Present-day dasycladalean algae are typical of warm, shallow bays and back-reef lagoons (Berger and Kaever 1992; Ohba et al. 2017). Consequently, it is thought that units 4-6, in which dasycladalean algae are common, were deposited in the back-reef lagoon of the Hoang Mai carbonate platform. This interpretation does not conflict with the common occurrence of a microbial framework in this carbonate succession.

\section{Isotope and minor element profiles}

To identify carbonate samples that likely retain the original seawater ${ }^{87} \mathrm{Sr} /{ }^{86} \mathrm{Sr}$, Denison et al. (1994) proposed criteria of $\mathrm{Sr} / \mathrm{Mn}>2$ or $\mathrm{Mn}<300 \mathrm{ppm}$. The $\mathrm{Mn} / \mathrm{Sr}$ ratio has also been proposed as a method to distinguish between diagenetically altered $(\mathrm{Mn} / \mathrm{Sr}>2)$ and unaltered $(\mathrm{Mn} / \mathrm{Sr}<2)$ carbonate samples for ${ }^{87} \mathrm{Sr} /{ }^{86} \mathrm{Sr}$ analysis (Jacobsen and Kaufman 1999). These criteria have been used to identify diagenetically altered carbonates, not only for ${ }^{87} \mathrm{Sr} /{ }^{86} \mathrm{Sr}$ analysis but also for $\delta^{13} \mathrm{C}$ and $\delta^{18} \mathrm{O}$ measurements. We define diagenetically altered samples as those with high Mn concentrations (>300 ppm) or with high $\mathrm{Mn} / \mathrm{Sr}$ values $(>2)$. By applying these definitions, 67 samples were identified as not having retained their initial $\delta^{13} \mathrm{C}$ and $\delta^{18} \mathrm{O}$ values.

The ${ }^{87} \mathrm{Sr} /{ }^{86} \mathrm{Sr}$ values of the carbonates studied here are much higher than that of global seawater during the Anisian (McArthur et al. 2001; Korte et al. 2003), irrespective of these criteria. Consequently, in this study, we estimate geologic ages from foraminiferal biostratigraphy rather than ${ }^{87} \mathrm{Sr} /{ }^{86} \mathrm{Sr}$ data. Possible explanations for the high ${ }^{87} \mathrm{Sr} /{ }^{86} \mathrm{Sr}$ values include diagenetic alteration by ${ }^{87} \mathrm{Sr}$-enriched waters. Such diagenesis has been reported for Cretaceous carbonates in the Middle East (e.g., Paganoni et al. 2016).

$\delta^{18} \mathrm{O}$ values in carbonates reflect the temperature of precipitation and the $\delta^{18} \mathrm{O}$ composition of the water from which they precipitated (e.g., Tucker and Wright 1990). Based on the equation relating the temperature, and the $\delta^{18} \mathrm{O}$ values of carbonates and the water (Friedman and
O'Neil 1977), and on conversion between the VPDB and VSMOW scales (Coplen et al. 1983), we can calculate the $\delta^{18} \mathrm{O}$ values of calcite precipitated in oxygen isotope equilibrium with ambient seawater (equilibrium calcite). Assuming that modern tropical open-ocean sea-surface temperatures $\left(20\right.$ to $\left.35^{\circ} \mathrm{C}\right)$ and $\delta^{18} \mathrm{O}$ values $(-1.5$ to $2.0 \%$ ) apply to Anisian seawater, the $\delta^{18} \mathrm{O}$ values of the equilibrium calcite are estimated to be -5.4 to $-1.1 \%$, which are higher than the values measured in the studied carbonates $(-9.3$ to $-4.4 \%)$. This indicates that the initial oxygen isotope composition of the studied carbonates has been reset by diagenesis. Alternatively, it is possible that the $\delta^{18} \mathrm{O}$ composition of Anisian seawater was much lower than modern-day values. The former interpretation is supported by the relatively low $\delta^{18} \mathrm{O}$ values measured in the diagenetic products, cement, and vein calcites found in the cores compared with those of the studied carbonates (Fig. 7).

The composite $\delta^{13} \mathrm{C}$ profile of the carbonate succession initially increases upwards from the base (lower interval, 130.0-76.5 mdfrh in core no. 1), followed by a prolonged gradual decrease upwards (middle interval, 76.5-0 mdfrh in core no. 1 and 160.0-52.9 mdfrh in core no. 4), with the upper interval characterized by a marked upwards decrease (41.8-0 mdfrh in core no. 4) (Fig. 6). The $\delta^{13} \mathrm{C}$ values of the succession fall in the $\delta^{13} \mathrm{C}$ range (-1.1 to $2.1 \%$ ) of Anisian whole-rock samples and brachiopod shells (Korte et al. 2005). The $\delta^{13} \mathrm{C}$ profiles of the lower and middle intervals are characterized by a smooth, systematic increase and decrease, respectively, with no distinctly anomalous values, and are correlated with coeval $\delta^{13} \mathrm{C}$ profiles in other areas as discussed below (Fig. 8). The $\delta^{13} \mathrm{C}$ and $\delta^{18} \mathrm{O}$ values from these intervals do not show a significant positive correlation (Fig. 7). Consequently, we consider that the carbonates in the lower and middle intervals have retained their initial $\delta^{13} \mathrm{C}$ values. Although the $\delta^{18} \mathrm{O}$ and ${ }^{87} \mathrm{Sr} /{ }^{86} \mathrm{Sr}$ values of carbonates are reset or modified by diagenesis, their $\delta^{13} \mathrm{C}$ values are commonly retained. As a result of the extreme differences in the concentrations of oxygen and carbon in diagenetic fluids, carbonate minerals equilibrate with fluid $\delta^{18} \mathrm{O}$ values at water:rock ratios $(<10)$ that are three orders of magnitude lower than those $\left(10^{3}\right)$ at which they equilibrate with fluid $\delta^{13} \mathrm{C}$ values (Banner and Hanson 1990). It is also shown that $\mathrm{Sr}-\mathrm{Ca}$-rich brines (similar to interstitial water in limestones) can also reset the ${ }^{87} \mathrm{Sr} /{ }^{86} \mathrm{Sr}$ values of a limestone at low water:rock ratios similar to those calculated for the equilibration of the $\delta^{18} \mathrm{O}$ values (Banner and Hanson 1990).

In contrast to the lower and middle intervals, the $\delta^{13} \mathrm{C}$ profile of the upper interval shows a marked decrease upwards (Fig. 3). This trend remains evident after removing the $\delta^{13} \mathrm{C}$ values of the 20 samples that were identified as being altered by diagenesis, based on $\mathrm{Mn}$ and Sr data (Fig. 7). Dissolution cavities filled by breccias with various clast sizes and laminated lime mud are 


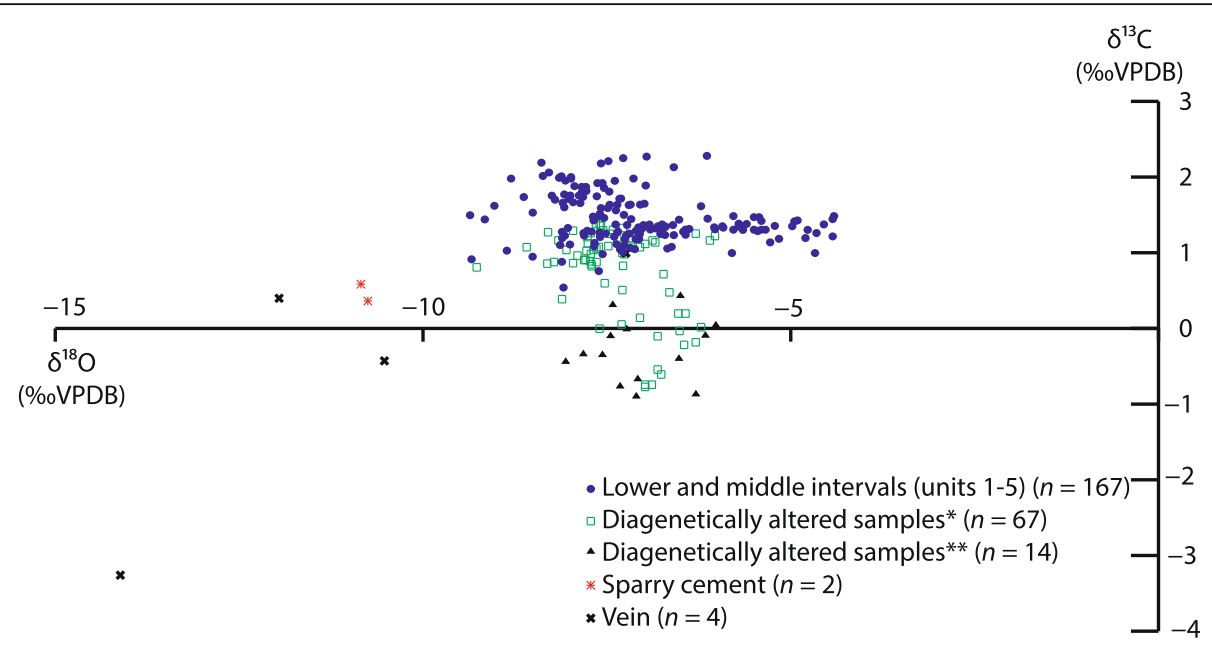

Fig. 7 Cross-plots displaying the relationship between $\delta^{13} \mathrm{C}$ and $\delta^{18} \mathrm{O}$ values of the studied bulk carbonate samples. Vein samples are from 1.14-1.20, 3.29-3.33, 120.39-120.43, and 148.68-148.72 mdfrh in core no. 4. Cement samples are from 82.28-82.32 and 136.33-136.39 mdfrh in core no. 4. *Samples identified as diagenetically altered based on trace element (Mn and Sr) criteria. **Samples that passed the geochemical screening for diagenetic alteration but were identified as altered based on petrographic observations (shown in gray in Fig. 6)

dominant in and immediately below the upper interval (upper $52.8 \mathrm{~m}$ of core 4; Fig. 3). Therefore, it is likely that the carbonates in the upper interval have been diagenetically altered and that the marked decrease in $\delta^{13} \mathrm{C}$ values was caused by diagenetic overprinting (i.e., meteoric diagenesis).

The $\delta^{13} \mathrm{C}$ profile of the studied carbonate succession is not controlled by facies changes altering the $\delta^{13} \mathrm{C}$ values of whole-rock samples because of the following two reasons. (1) The $\delta^{13} \mathrm{C}$ values do not show any distinct changes at lithological boundaries (unit boundaries); and (2) it is reported that microbially induced micrite is usually depleted in ${ }^{12} \mathrm{C}$, relative to marine carbonates ( $\mathrm{Wu}$ and Chafets 2002). There is, however, no increase in $\delta^{13} \mathrm{C}$ values related to sedimentary facies dominated by microbial products such as oncoids and microbialite (units 3 and 5).

\section{Correlation of the $\delta^{13} \mathrm{C}$ profiles with other areas}

To understand if the Vietnamese $\delta^{13} \mathrm{C}$ profile represents changes in the $\delta^{13} \mathrm{C}$ of dissolved inorganic carbon $\left(\delta^{13} C_{\text {DIC }}\right)$ in global seawater during the Bithynian-Pelsonian (Anisian), we compare our profile with regional studies that are considered the same interval.

Several studies have shown temporal variations in the $\delta^{13} \mathrm{C}$ values of carbonates through the Anisian (Fig. 8, Additional file 3: Figure S1). Examples include carbonates from Kamura, Japan (Zhang et al. 2017; Additional file 3: Figure S1k); the Eastern Sichuan Basin, China (Huang et al. 2012); Nanpanjiang, South China (Payne et al. 2004; Sun et al. 2012; Lehrmann et al. 2015; Additional file 3: Figure S1 h, i, j); Thongde in the Zanskar Himalayas, India (Baud et al. 1989; Additional file 3: Figure S1f); Himachal
Pradesh, India (Galfetti et al. 2007); Sal Formation, WNW of the village of Sal, Oman (Hauser et al. 2001); the Taşkent section in the Aladag Nappe, Turkey (Lau et al. 2016); North Dobrogea, Romania (Atudorei et al. 1997; Additional file 3: Figure S1e); the Tatra Mountains, Poland (Jaglarz and Szulc 2003; Additional file 3: Figure S1d); the Germanic Basin, Germany (Szulc 2000; Additional file 3: Figure S1c); the Belanské Tatry Mountains, Slovakia (Rychliński and Szulc 2005; Additional file 3: Figure S1b); North Switzerland (Feist-Burkhardt et al. 2008; Additional file 3: Figure S1a); and the Dolomites and Lagonegro Basin in northern and southern Italy, respectively (Preto et al. 2009). To correlate these $\delta^{13} \mathrm{C}$ profiles and provide chronological constraints, we used the reported foraminiferal, conodont, and ammonoid biostratigraphies along with known regional stratigraphic frameworks (Additional file 3: Figure S1). Based on the chronologies used, the $\delta^{13} \mathrm{C}$ profiles are not necessarily coincident with each other. This result contrasts with the widely accepted chemostratigraphic frameworks for the upper Barremian to the upper Aptian (e.g., Menegatti et al. 1998; Yamamoto et al. 2013) and the Cenomanian to the Turonian (e.g., Herrle et al. 2015; Gyawali et al. 2017).

The higher-resolution $\delta^{13} \mathrm{C}$ sampling of the profiles of North Dobrogea (Fig. 8a) and the three sections in the Nanpanjiang Basin (Bianyang (Fig. 8c), Guandao II (Fig. 8d), and Guandao (Fig. 8e)) makes these sections relatively reliable in terms of comparing with the Vietnamese $\delta^{13} \mathrm{C}$ profile (Fig. $8 \mathrm{~b}$ ). The other sections, mentioned above, have a low-resolution carbon isotope stratigraphy (Baud et al. 1989; Szulc 2000; Hauser et al. 2001; Jaglarz and Szulc 2003; Feist-Burkhardt et al. 2008; Lau et al. 2016; Zhang et al. 2017), poor age control (Rychliński and 


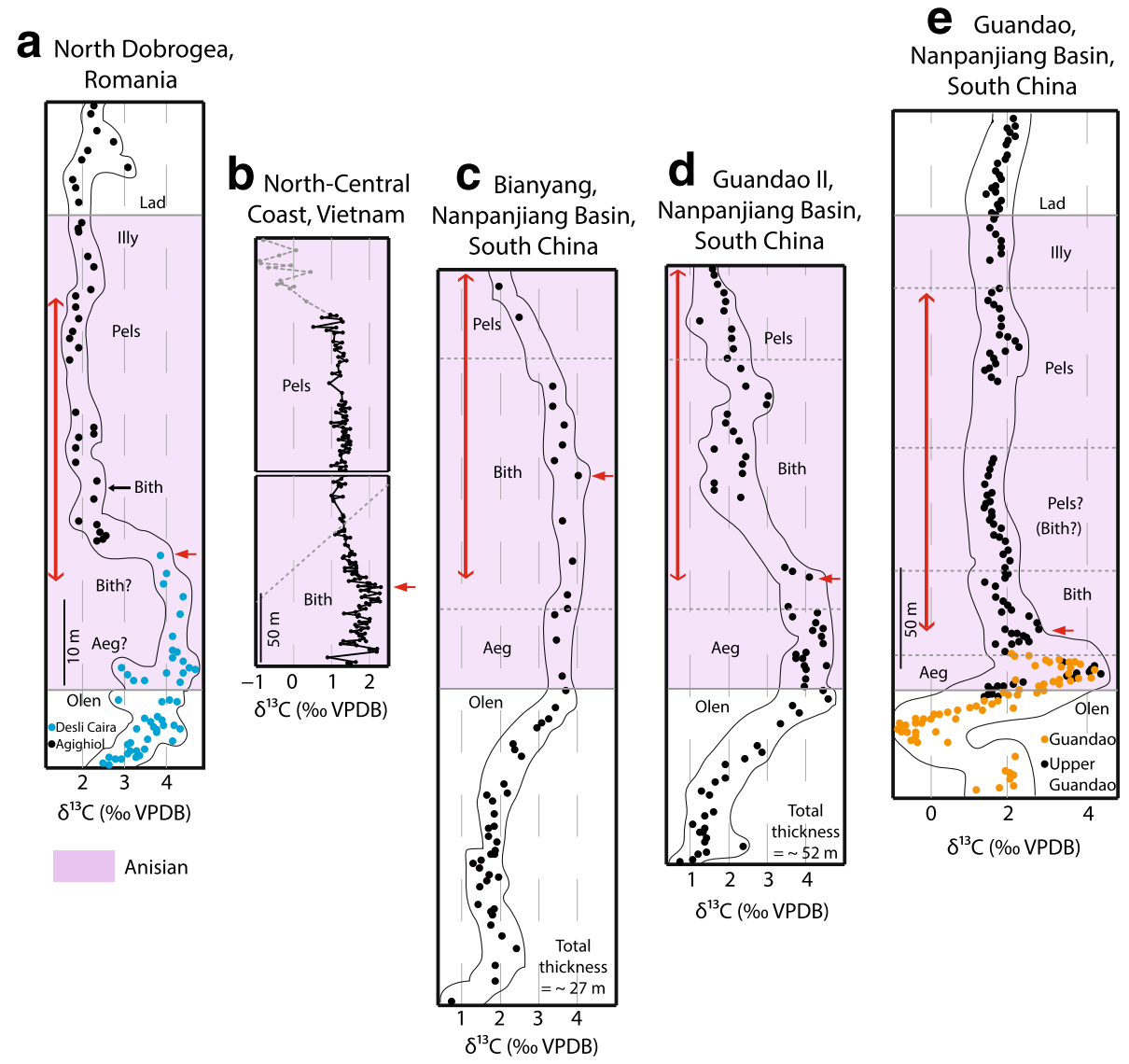

Fig. 8 Anisian $\delta^{13} C$ profiles of carbonates from Romania, Vietnam, and South China. a North Dobrogea, Romania (Atudorei et al. 1997); b North-Central Coast region, Vietnam (this study); c Bianyang section, Nanpanjiang Basin, South China (Sun et al. 2012); d Guandao II section, Nanpanjiang Basin, South China (Sun et al. 2012); e Guandao section, Nanpanjiang Basin, South China (Payne et al. 2004). The vertical red double arrows indicate the interval represented by the studied carbonate succession in Vietnam. The small horizontal arrows indicate the basal horizon of the Bithynian $\delta^{13} \mathrm{C}$ decrease followed by the interval of prolonged (Bithynian-Pelsonian) stability or gradual decrease in values, as reported from South China and Romania. Abbreviations: Aeg, Aegean; Bith, Bithynian; Illy, Illyrian; Lad, Ladinian; Olen, Olenekian; Pels, Pelsonian

Szulc 2005; Feist-Burkhardt et al. 2008), and have been influenced by local changes in water chemistry such as freshwater influx and high organic carbon burial flux in the basin (Szulc 2000; Huang et al. 2012).

The Vietnamese $\delta^{13} \mathrm{C}$ profile is characterized by a slight increase upwards in the lower interval, followed by a gradual decrease in the middle interval, which, based on foraminiferal biostratigraphy, started during the Bithynian and continued into the Pelsonian (Fig. 6) - Similar trends are recognized in the Romanian and South China $\delta^{13} \mathrm{C}$ profiles (Fig. 8). The Bithynian-Pelsonian carbonate $\delta^{13} \mathrm{C}$ profile from North Dobrogea (Fig. 8a; Atudorei et al. 1997) shows an interval with high $\delta^{13} \mathrm{C}$ values $(\sim 4 \%)$, followed by a prolonged stable interval with lower values of $\sim 2 \%$. A distinct negative isotope excursion of $\sim 2 \%$ occurs in the $\mathrm{Bi}$ thynian, although this excursion might reflect the control of lithological facies on the carbon isotope composition. The $\delta^{13} \mathrm{C}$ profile from North Dobrogea is based on data from the Desli Caira and Agighiol sections, and the isotope excursion corresponds to the boundary between the two sections. The Bithynian-Pelsonian carbonate $\delta^{13} \mathrm{C}$ profile of the Guandao II section (Fig. 8d; Sun et al. 2012) shows an interval of high values $(\sim 4 \%)$ followed by an interval of lower values $(\sim 2 \%)$, with the negative isotope excursion between the two intervals occurring in the $\mathrm{Bi}$ thynian. The Bithynian-Pelsonian carbonate $\delta^{13} \mathrm{C}$ profile of the Bianyang section also shows a decreasing upwards trend, starting in the Bithynian, from $\sim 4$ to $\sim 2 \%$; however, this trend is gradual rather than abrupt (Fig. 8c; Sun et al. 2012). The carbonate $\delta^{13} \mathrm{C}$ profile of the Guandao section exhibits positive and negative excursions ( $\sim 1 \%$ each $)$ in the Bithynian followed by a prolonged stable interval with values of $\sim 2 \%$ in the Bithynian and Pelsonian (Fig. 8e; Payne et al. 2004). Although these $\delta^{13} \mathrm{C}$ profiles do not correlate precisely, they all display a Bithynian $\delta^{13} \mathrm{C}$ 
decrease followed by an interval of prolonged (Bithynian-Pelsonian) stability or gradual $\delta^{13} \mathrm{C}$ decrease.

A possible explanation for the differences observed in the abovementioned $\delta^{13} \mathrm{C}$ profiles include local, basin-wide, and global heterogeneities in the $\delta^{13} C_{\text {DIC }}$ in seawater, which must be taken into account when interpreting geochemical records of ancient seas (Immenhauser et al. 2003, 2008). Carbonates formed on platforms with enhanced biological carbon uptake are depleted in ${ }^{12} \mathrm{C}$ compared with shelf and basin carbonates. The $\delta^{13} \mathrm{C}$ values of the carbonates in this study, however, are not significantly higher than those of other areas. Szulc (2000) relates Middle Triassic variations in $\delta^{13} \mathrm{C}$ (and $\delta^{18} \mathrm{O}$ ) values to changes in water chemistry (e.g., freshwater influx) caused by sea-level changes and meteoric diagenesis. Therefore, some of the $\delta^{13} \mathrm{C}$ profiles might record local phenomena, which is likely to at least partially contribute to the discrepancies among the studies. The Vietnamese $\delta^{13} \mathrm{C}$ profile probably represents global changes in seawater $\delta^{13} C_{\text {DIC }}$ values, except for the upper interval, as the studied succession was formed on a carbonate platform and represents a continuous depositional record without erosional surfaces. The middle to late Anisian (Bithynian to Pelsonian) interval of relatively stable $\delta^{13} \mathrm{C}$ values suggests that no global carbon-cycle perturbations occurred during this time.

\section{Conclusions}

We conducted an integrated study on the lithostratigraphy, biostratigraphy, and chemostratigraphy of carbonates in two drill cores from the Middle Triassic Hoang Mai Formation in Nghe An Province in the North-Central Coast region of Vietnam. The cores cover a 150-190 m-thick carbonate succession. The main conclusions are as follows.

1. The carbonates consist of the following six lithostratigraphic units (from bottom to top): sandy limestone (unit 1), peloidal packstone with a microbialite interlayer (unit 2), peloidal packstone and oncoidal floatstone (unit 3), peloid bioclast packstone (unit 4), peloidal packstone with variable quantities of bioclasts and microbialite (unit 5), and peloidal packstone with variable amounts of bioclasts (unit 6). The sandy nature of unit 1 and of three interlayers in unit 2, along with dark rock color of these units, indicates a supply of terrigenous material in the early stage of the Hoang Mai carbonate platform. The predominance of carbonate with a finegrained matrix throughout the overlying units (2-6) suggests a low-energy depositional environment. We infer that unit 3 , which contains abundant oncoids, was formed and deposited in such a low-energy environment. It is likely that units 4-6, with abundant dasycladalean algae, were deposited in a back-reef lagoon environment.
2. A total of 24 foraminiferal taxa were identified from 68 stratigraphic levels. The middle-upper parts of the examined core succession (units 3-6) are inferred to be Pelsonian in age, based principally on the occurrence of Citaella dinarica and C.? deformata, and secondarily on the presence of Endotriadella wirzi, E. pentacamerata, and Endotriada tyrrhenica. Units 1 and 2 are probably attributed to the Bithynian. Thus, the entire core succession is considered to be middle Anisian (early Middle Triassic).

3. The ${ }^{87} \mathrm{Sr} /{ }^{86} \mathrm{Sr}$ values measured in the carbonates are higher than that of global seawater during the Middle Triassic. The low $\delta^{18} \mathrm{O}$ values of the carbonates indicate that their initial oxygen isotope composition has been reset. The $\delta^{13} \mathrm{C}$ profile of the lower and middle intervals displays a slight increase upwards, followed by a prolonged gradual decrease. The $\delta^{13} \mathrm{C}$ values fall within a narrow range of 1.0$2.0 \%$ and do not show positive or negative isotope excursions. This $\delta^{13} \mathrm{C}$ trend can be correlated with the Bithynian decrease followed by a prolonged interval (Bithynian-Pelsonian) of stability or gradual decrease in $\delta^{13} \mathrm{C}$ values, as reported from sections in South China and Romania. The upper interval of the Vietnamese $\delta^{13} \mathrm{C}$ profile is characterized by a marked decrease to the core top that likely reflects diagenetic overprinting.

\section{Additional files}

Additional file 1: Table $\mathbf{S 1} . \delta^{13} \mathrm{C}$ and $\delta^{18} \mathrm{O}$ values, minor element ( $\mathrm{Sr}, \mathrm{Mn}$, and $\mathrm{Fe}$ ) concentrations, and ${ }^{87} \mathrm{Sr} /{ }^{86} \mathrm{Sr}$ values of bulk carbonate samples from Core No. 1. Diagenetically altered samples are those with high Mn concentrations (> $300 \mathrm{ppm}$ ) or with high $\mathrm{Mn} / \mathrm{Sr}$ values $(>2)$. (PDF $66 \mathrm{~kb}$ )

Additional file 2: Table $\mathrm{S2} . \delta^{13} \mathrm{C}$ and $\delta^{18} \mathrm{O}$ values, minor element ( $\mathrm{Sr}, \mathrm{Mn}$, and $\mathrm{Fe}$ ) concentrations, and ${ }^{87} \mathrm{Sr} /{ }^{86} \mathrm{Sr}$ values of bulk carbonate samples from Core No. 4. Diagenetically altered samples are those with high Mn concentrations (> $300 \mathrm{ppm}$ ) or with high Mn/Sr values (> 2). (PDF $65 \mathrm{~kb}$ )

Additional file 3: Figure S1. Anisian $\delta^{13} \mathrm{C}$ profiles of carbonates from various sites/sections. a, North Switzerland (Feist-Burkhardt et al. 2008); b, Belanské Tatry Mountains, Slovakia (Rychliński and Szulc 2005); c, Germanic Basin, Germany (Szulc 2000); d, Polish Tatra Mountains (Jaglarz and Szulc 2003); e, North Dobrogea, Romania (Atudorei et al. 1997); f, Thongde in the Zanskar Himalayas, India (Baud et al. 1989); g, North-Central Coast region, Vietnam (this study); h, Bianyang, Nanpanjiang, South China (Sun et al. 2012); i, Guandao II, Nanpanjiang, South China (Sun et al. 2012), j, Guandao, Nanpanjiang, South China (Payne et al. 2004); k, Kamura, Japan (Zhang et al. 2017). The vertical red double arrows indicate the interval represented by the studied carbonate succession in Vietnam. The small horizontal arrows indicate the basal horizon of the Bithynian $\delta^{13} \mathrm{C}$ decrease followed by the interval of prolonged (Bithynian-Pelsonian) stability or gradual decrease in values, as reported from South China and Romania. Abbreviations: Aeg, Aegean; Bith, Bithynian; Illy, Illyrian; Lad, Ladinian; Olen, Olenekian; Pels, Pelsonian. (PDF $661 \mathrm{~kb}$ )

\section{Abbreviations}

mdfrh: Meters depth from the reference horizon; VPDB: Vienna Pee Dee Belemnite; VSMOW: Vienna Standard Mean Ocean Water 


\section{Acknowledgments}

The manuscript was significantly improved by the comments and suggestions of Prof. Tada (Editor) and two anonymous reviewers.

\section{Authors' contributions}

$\mathrm{TTNH}$ and $\mathrm{Yl}$ conceptualized and designed this study. TTNH and $\mathrm{YI}$ conducted the fieldwork and sampling. TTNH, HT, YA, and KY carried out the chemical and isotopic analysis. KU performed biostratigraphic analysis. $\mathrm{TTNH}, \mathrm{HT}$, and $\mathrm{KU}$ collaborated with the corresponding author in the interpretation of the data and the construction of the manuscript. All authors read and approved the final manuscript.

\section{Funding}

This work was supported by Grant-in-Aid for Scientific Research from the Japan Society for the Promotion of Science to Y.I. (26302008) and K.U. (18 K03829).

\section{Availability of data and materials}

Please contact the corresponding author regarding data requests.

\section{Competing interests}

The authors declare that they have no competing interests.

\section{Author details}

${ }^{1}$ Department of Earth Science, Graduate School of Science, Tohoku University, Sendai 980-8578, Japan. ²Department of Earth System Science, Fukuoka University, Fukuoka 814-0180, Japan. ${ }^{3}$ Department of Earth and Environmental Sciences, Nagoya University, Nagoya 464-8601, Japan.

Received: 26 November 2018 Accepted: 7 June 2019

\section{Published online: 08 July 2019}

\section{References}

Asahara Y, Ishiguro H, Tanaka T, Yamamoto K, Miura K, Minami M, Yoshida H (2006) Application of Sr isotopes to geochemical mapping and provenance analysis: the case of Aichi Prefecture, central Japan. Appl Geochem 21(3): 419-436. https://doi.org/10.1016/j.apgeochem.2005.12.003

Asahara Y, Tanaka T, Kamioka H, Nishimura A, Yamazaki T (1999) Provenance of the north Pacific sediments and process of source material transport as derived from Rb-Sr isotopic systematics. Chem Geol 158(3-4):271-291. https://doi.org/10.1016/S0009-2541(99)00056-X

Atudorei V, Baud A, Crasquin-Soleau S, Galbrun B, Gradinaru E, Mirauta E, Renard M, Zerrari S (1997) Extended scientific report of the Peri Tethys Project: The Triassic of North-Dobrogea. https://www.pim.uzh.ch/_files/_downloads/ Dobrogea_Triassic_Report_1997.pdf\#search=\%27EXTENDED+SCIENTIFIC+ REPORT+OF+THE+PERITETHYS+PROJECT+THE+TRIASSIC+OF+ NORTHDOBROGEA\%27. Accessed 1 Aug 2018

Banner JL, Hanson GN (1990) Calculation of simultaneous isotopic and trace element variations during water-rock interaction with applications to carbonate diagenesis. Geochim Cosmochim Acta 54:123-3137. https://doi. org/10.1016/0016-7037(90)90128-8

Baud A, Magaritz M, Holser WT (1989) Permian-Triassic of the Tethys: carbon isotope studies. Geol Rundsch 78:649-677. https://doi.org/10.1007/BF01776196

Berger S, Kaever MJ (1992) Dasycladales: an illustrated monograph of a fascinating algal order. G. Thieme Verlag, Stuttgart

Cai X, Zhang KJ (2009) A new model for the Indochina and South China collision during the Late Permian to the Middle Triassic. Tectonophysics 467:35-43. https://doi.org/10.1016/j.tecto.2008.12.003

Coplen TB, Kendall C, Hopple J (1983) Comparison of stable isotope reference samples. Nature 302:236-238. https://doi.org/10.1038/302236a0

Dang TH (2006) Mesozoic. In: Tong DT, Vu K (eds) Stratigraphic units of Vietnam. Viet Nat Univ Publ House, Hanoi

Denison RE, Koepnick RB, Fletcher A, Howell MW, Callaway WS (1994) Criteria for the retention of orginal seawater ${ }^{87} \mathrm{Sr} /{ }^{86} \mathrm{Sr}$ in ancient shelf limestones. Chem Geol 112:131-143. https://doi.org/10.1016/0009-2541(94)90110-4

Do T (1983) Geomorphological features of Ninh Binh area and their formation processes. Geology 159:27-30 (in Vietnamese; original title translated)

Faure M, Lepvrier C, Nguyen W, Vu VT, Lind W, Chend Z (2014) The South China block-Indochina collision: where, when, and how? J Asian Earth Sci 79:260-274. https://doi.org/10.1016/j.jseaes.2013.09.022

Feist-Burkhardt S, Gotz AE, Ruckwied K, Russell JW (2008) Palynofacies patterns, acritarch diversity and stable isotope signatures in the Lower Muschelkalk
(Middle Triassic) of N Switzerland: Evidence of third-order cyclicity. Swiss J Geosci 101:1-15. https://doi.org/10.1007/s00015-00701235-z

Friedman I, O'Neil JR (1977) Compilation of stable isotope fractionation factors geochemical interest. In: Fleischer M (ed) Data of geochemistry, sixth edition. US Geol Surv Prof Paper 440-KK. US Gov Print Off, Washington D. C.

Galfetti T, Bucher H, Brayard A, Peter A, Hochuli PA, Weissert H, Guodun K, Atudorei V, Guex J (2007) Late Early Triassic climate change: insights from carbonate carbon isotopes, sedimentary evolution and ammonoid paleobiogeography. Palaeogeogr Palaeoclimatol Palaeoecol 243:394-411. https:/doi.org/10.1016/.jpalaeo.2006.08.014

Gaździcki A, Trammer J, Zawidzka K (1975) Foraminifers from the Muschelkalk of Southern Poland. Acta Geol Pol 25:285-298

Geological Survey of Vietnam (1995) Geological and mineral resources map of Vietnam, 1:200,000, Vinh. Geological Survey of Vietnam, Hanoi

Gyawali BR, Nishi H, Takashima R, Herrle JO, Takayanagi H, Latil JL, Iryu Y (2017) Upper Albian-upper Turonian calcareous nannofossil biostratigraphy and chemostratigraphy in the Vocontian Basin, southeastern France. Newslet Stratigr 50:111-139. https://doi.org/10.1127/nos/2016/0339

Hauser M, Martini R, Burns S, Dumitrica P, Krystyn L, Matter A, Peters T, Zaninetti L (2001) Triassic stratigraphic evolution of the Arabian-Greater India embayment of the southern Tethys margin. Ecl Geol Helv 94:29-62. https:// doi.org/10.5169/seals-168876

Herrle JO, Schröder-Adams CJ, Davis W, Pugh AT, Galloway JM, Fath J (2015) MidCretaceous high arctic stratigraphy, climate, and oceanic anoxic events. Geology 43:403-406. https://doi.org/10.1130/G36439.1

Huang SJ, Huang KK, Lu J, Lan YF (2012) Carbon isotopic composition of Early Triassic marine carbonates, Eastern Sichuan Basin, China. Sci China Ear Sci 55: 2026-2038. https://doi.org/10.1007/s11430-012-4440-1

Immenhauser A, Holmden C, Patterson WP (2008) Interpreting the carbonisotope record of ancient shallow epeiric seas: lessons from the recent. In: Pratt B, Holmden C (eds) Dynamics of Epeiric Seas. Geol Ass Canada Spec Paper 48. Geol Ass Canada, St. John's, pp 135-174

Immenhauser AG, Porta D, Kenter JAM, Bahamonde JR (2003) An alternative model for positive shifts in shallow-marine carbonate $\delta^{13} \mathrm{C}$ and $\delta^{18} \mathrm{O}$ Sedimentology 50:953-959. https://doi.org/10.1046/j.1365-3091.2003.00590.x

Jacobsen SB, Kaufman AJ (1999) The Sr, C and O isotopic evolution of Neoproterozoic seawater. Chem Geol 161:37-57. https://doi.org/10.1016/ S0009-2541(99)00080-7

Jaglarz P, Szulc J (2003) Middle Triassic evolution of the Tatricum sedimentatry basin: an attempt of sequence stratigraphy to the Wierchowa unit in the Polish Tatra Mountains. Ann Soc Geol Pol 73:169-182

Jiménez-López C, Romanek CS, Huertas FJ, Ohmoto H, Caballero E (2004) Oxygen isotope fractionation in synthetic magnesian calcite. Geochim Cosmochim Acta 68:3367-3377. https://doi.org/10.1016/j.gca.2003.11.033

Khuc V (2000) The Triassic of Indochina Peninsula and its interregional correlation. In: Yin H, Dickins JM, Shi GR, Tong J (eds) Permian-Triassic evolution of Tethys and Western Circum-Pacific. Devel Palaeontol Stratigr 18. Elsevier, Amsterdam, pp 221-233

Kochansky-Devidé V, Pantić Ś (1966) Meandrospira in der unteren und mittleren Trias sowie einige begleitende Fossilien in den Dinariden. Geološki Vjesnik 19(1965):15-28

Koehn-Zaninetti L (1969) Les foraminifères du Trias de la région de l'Almtal (Haute-Autriche). Jahrb Geol Bundesanst Sonderb 14:1-155

Korte C, Kozur HW, Bruckschen P, Veizer J (2003) Strontium isotope evolution of late Permian and Triassic seawater. Geochim Cosmochim Acta 67:47-62

Korte C, Kozur HW, Veizer J (2005) $\delta^{13} \mathrm{C}$ and $\delta^{18} \mathrm{O}$ values of Triassic brachiopods and carbonate rocks as proxies for coeval seawater and palaeotemperature. Palaeogeogr Palaeoclimatol Palaeoecol 226:287-306. https://doi.org/10.1016/ j.palaeo.2005.05.018

Lau KV, Maher K, Altiner D, Kelley BM, Kump LR, Lehrmann DJ, Tamayo JCS, Weaver KL, Yu M, Payne $J$ (2016) Marine anoxia and delayed Earth system recovery after the end- Permian extinction. PNAS 113:9. https://doi.org/10. 1073/pnas.1515080113

Lehrmann DJ, Stepchinski L, Altiner D, Orchard MJ, Montgomery P, Enos P, Ellwood BB, Bowring SA, Ramezani J, Wang H, Wei J, Yu M, Griffiths JD, Minzoni M, Schaal EK, Li X, Meyer KM, Payne JL (2015) An integrated biostratigraphy (conodonts and foraminifers) and chronostratigraphy (paleomagnetic reversals, magnetic susceptibility, elemental chemistry, carbon isotopes and geochronology) for the Permian-Upper Triassic strata of Guandao section, Nanpanjiang Basin, South China. J Asian Earth Sci 108:117-135. https://doi.org/10.1016/j. jseaes.2015.04.030 
Lepvrier C, Maluski H, Tich W, Leyreloup A, Thi PT, Vuong NV (2004) The Early Triassic Indosinian orogeny in Vietnam (Truong son Belt and Kontum Massif): implications for the geodynamic evolution of Indochina. Tectonophysics 393:87-118. https://doi.org/10.1016/j.tecto.2004.07.030

Lepvrier C, Vuong NV, Maluski H, Thi PT, Vu TV (2008) Indosinian tectonics in Vietnam. C R Geosci 340:94-111. https://doi.org/10.1016/j.crte.2007.10.005

Liem NV (1966) Some Triassic foraminifera from the Hoang Mai Limestone, Nghe An Province, Northern Vietnam. Acta Sci Vietnam Sec Biol Geol Geogr 1:37-44

Liem NV (1973) On some Triassic Foraminifera recently collected from northern Vietnam. Geology 106:16-19 (in Vietnamese; original title translated)

Martindale RC, Corsetti FA, James NP, Bottjer DJ (2015) Paleogeographic trends in Late Triassic reef ecology from Northeastern Panthalassa. Earth Sci Rev 142: 18-37. https://doi.org/10.1016/j.earscirev.2014.12.004

Matsuda S, Iryu Y (2011) Rhodoliths in the deep fore-reef to insular shelf areas around Okinawa-jima, Ryukyu Islands, Japan. Mar Geol 282:215-230. https:// doi.org/10.1016/j.margeo.2011.02.013

McArthur JM, Howarth RJ, Bailey TR (2001) Strontium isotope stratigraphy: LOWESS version 3: best fit to the marine Sr-isotope curve for 0-509 Ma and accompanying look-up table for deriving numerical age. J Geol 109: $155-170$

Menegatti AP, Wessert H, Brown RS, Tyson RV, Farrimond P, Strasser A, Caron M (1998) High resolution $\delta^{13} \mathrm{C}$ stratigraphy through the early Aptian "Livello Selli" of the Alpine Tethys. Paleoceanography 13:5 530-5 545. https://doi.org/10.1029/98PA01793

Metcalfe I (2011) Palaeozoic-Mesozoic history of SE Asia. In: Hall R, Cottam MA, Wilson MEJ (eds) The SE Asian Gateway: History and Tectonics of the Australia-Asia collision. Geol Soc London Spe Publ, 355. Geol Soc, London, pp 7-35. https://doi.org/10.1144/SP355.2

Metcalfe I (2012) Changhsingian (Late Permian) conodonts from Son La, northwest Vietnam and their stratigraphic and tectonic implications. J Asian Earth Sci 50:141-149. https://doi.org/10.1016/j.jseaes.2012.01.002

Miyahigashi A, Hara H, Hisada K, Nakano N, Charoentitirat T, Charusiri P, Khamphavong K, Martini R, Ueno K (2017) Middle Triassic foraminifers from northern Laos and their paleobiogeographic significance. Geobios 50:441-451

Nam TN (1995) The geology of Vietnam: a brief summary and problems. Geosci Repts Shizuoka Univ 22:1-9

Ohba H, Matsuda S, Asami R, Iryu Y (2017) Recent Dasycladales (Chlorophyta) in Okinawa Jima in the Central Ryukyus, southwestern Japan: paleontological implications. Island Arc 26:e12185. https://doi.org/10.1111/iar.12185

Oraveczné Scheffer A (1987) Triassic Foraminifers of the Transdanubian Central Range: Geologica Hungarica. Series Palaeontologica 50:7-331

Osanai Y, Nakano N, Owada M, Nam TN, Miyamoto T, Minh NT, Nam NV, Tri TV (2008) Collision zone metamorphism in Vietnam and adjacent South-Eastern Asia: proposition for Trans Vietnam Orogenic Belt. J Mineral Petrol Sci 103: 226-241. https://doi.org/10.2465/jmps.080620e

Paganoni M, Al Harthi A, Morad D, Morad S, Ceriani A, Mansurbeg H, Al Suwaidi S, Al-Aasm IS, Ehrenberg SN, Sirat M (2016) Impact of stylolitization on diagenesis of a lower Cretaceous carbonate reservoir from a giant oilfield, Abu Dhabi, United Arab Emirates. Sedim Geol 335: 70-92. https://doi.org/10.1016/j.sedgeo.2016.02.004

Pantić S (1964) Pilammina densa n. gen., n. sp. and other Ammodiscidae from the Middle Triassic in Crmnica (Montenegro). Geološki Vjesnik Zagreb 18:189-193

Payne JL, Lehrmann DJ, Wei J, Orchard MJ, Schrag DP, Knoll AH (2004) Large perturbations of the carbon cycle during recovery from the end-Permian extinction. Science 305:506-509. https://doi.org/10.1126/science.1097023

Prager EJ, Ginsburg RN (1989) Carbonate nodule growth on Florida's outer shelf and its implications for fossil interpretations. Palaios 4:310-317. https://doi. org/10.2307/3514555

Preto N, Spotl C, Guaiumi C (2009) Evaluation of bulk carbonate $\delta^{13} \mathrm{C}$ data from Triassic hemipelagites and the initial composition of carbonate mud. Sedimentology 56:1329-1345. https://doi.org/10.1111/j.1365-3091.2008.01036.x

Rettori R (1995) Foraminiferi del Trias inferiore e medio della Tetide: revisione tassonomica, stratigrafia ed inerpretazione filogenetica. Publications du Département de Géologie et Paléontologie, Université de Genève 18, $147 \mathrm{p}$

Rychliński T, Szulc J (2005) Facies and sedimentary environments of the upper Scythian-Carnian succession from the Belanske Tatry Mts., Slovakia. Ann Soc Geol Pol 75:155-169
Salaj J (1977) Contribution à la microbiostratigraphie du Trias des Carpates Occidentales Tchécoslovaques. Ann Min Géol 28:103-127

Salaj J, Biely A, Bystrický J (1967) Trias-Foraminiferen in den Westkarpaten. Geologické Práce, Zprávy 42:119-136

Salaj J, Borza K, Samuel O (1983) Triassic foraminifers of the West Carpathians. Geologický ústav Dionýza Štúra, Bratislava

Saltzman MR, Thomas E (2012) Carbon isotope stratigraphy. In: Gradstein FM, Ogg JG, Schmitz M, Ogg G (eds) The geologic time scale, volume 1. Elsevier, Amsterdam, pp 207-232

Shigeta Y, Komatsu T, Nguyen DH, Dang TH, Iwakiri N (2010) Discovery of the Middle Triassic ammonoid Balatonites in the Quy Lang Formation, Thanh Hoa Province, Central Vietnam. Paleontol Res 14:244-249. https://doi.org/10. 2517/1342-8144-14.4.244

Sun $Y$, Joachimski MM, Wignall PB, Yan C, Chen $Y$, Jiang $H$, Wang L, Lai X (2012) Lethally hot temperatures during the Early Triassic greenhouse. Science 338:366-370. https://doi.org/10.1126/science.1224126

Suzuki K, Asahara Y, Mimura K, Tanaka T (2012) Another sea area separated from the Panthalassic Ocean in the Norian, the Late Triassic: the lowest $\mathrm{Sr}$ isotopic composition of the Ishimaki limestone in central Japan. Chem Erde 72(1):77-84

Suzuki $Y$, Iryu $Y$, Inagaki S, Yamada T, Aizawa S, Budd DA (2006) Origin of atoll dolomites distinguished by geochemistry and crystal chemistry: Kita-daito-jima, northern Philippine Sea. Sediment Geol 183:181-202. https://doi.org/10.1016/j.sedgeo.2005.09.016

Szulc J (2000) Middle Triassic Evolution of the Northern Peri-Tethys area as influenced by early opening of the Tethys Ocean. Ann Soc Geol Pol 70:1-48

Tapponnier P, Lacassin R, Leloup PH, Scharer U, Zhong D, Wu H, Liu X, Ji S, Zhang L, Zhong J (1990) The Ailao Shan-Red River metamorphic belt: tertiary left-lateral shear between Sundaland and South China. Nature 343:431-437. https://doi.org/10.1038/343431a0

Tarutani T, Clayton RN, Mayeda TK (1969) The effect of polymorphism and magnesium subtitution on oxygen isotope fractionation between calcium carbonate and water. Geochim Cosmochim Acta 33:987-996. https://doi.org/10.1016/0016-7037(69)90108-2

Thanh TD, Khuc V (eds) (2011) Stratigraphic units of Vietnam. Vietnam Nat Univ Publ House, Hanoi

Tucker ME, Wright VP (1990) Carbonate Sedimentology. Blackwell Sci Publ, London

Udchachon M, Thassanapak H, Feng Q, Burrett C (2017) Palaeoenvironmental implications of geochemistry and radiolarians from Upper Devonian chert/shale sequences of the Truong Son fold belt, Laos. Geol J 52:154173. https://doi.org/10.1002/gj.2743

Ueno K, Ha TNT, Iryu Y (2019) Foraminiferal biochronology of the Triassic Hoang Mai Formation, Central Vietnam. J Foram Res 49:339-354

Ueno K, Miyahigashi A, Martini R (2018) Taxonomic and nomenclatural justification for the Triassic meandrospiral foraminiferal genus Citaella Premoli Silva, 1964. J Foram Res 48:62-74

Vachard D, Martini R, Rettori R, Zaninetti L (1994) Nouvelle classification des foraminifères endothyroïdes du Trias. Geobios 27:543-557

Velledits F, Péró C, Blau J, Senowbari-Daryan B, Kovács S, Piros O, Pocsai T, Szügyi-Simon H, Dumitrică P, Pálfy J (2011) The oldest Triassic platform margin reef from the Alpine-Carpathian region (Aggtelek, Ne Hungary): platform evolution, reefal biota and biostratigraphic framework. Riv Ital Paleontol Stratigr 117:221-268

Vu K (1984) Triassic Ammonoids in Vietnam. General Geological Department, Hanoi (in Vietnamese with English summary)

Vu K (1991) Paleontological Atlas of Vietnam, Vol. 3, Mollusca. Science and Technics Publishing House, Hanoi

Vu K, Trinh T (1969) The detailed division of the Middle Triassic Quy Lang Formation in northern Nghe An Province, based on paleontological data. Geology 83-84:49-47 (in Vietnamese; original title translated)

Vu K, Trinh T, Le T (1972) New document about the Early Triassic-Middle Triassic stratigraphy in Thanh Hoa, Ninh Binh, Hoa Binh. Geology 102:525 (in Vietnamese; original title translated)

Wu Y, Chafets S (2002) ${ }^{13}$ C-enriched carbonate in Mississippian mud mounds: Alamogordo Member, Lake Valley Formation, Sacramento Mountains, New Mexico, U.S.A. J Sedim Res 72:138-145. https://doi.org/ 10.1306/040201720138

Yamamoto K, Ishibashi M, Takayanagi $H$, Asahara $Y$, Sato T, Nishi H, Iryu $Y$ (2013) Early Aptian paleoenvironmental evolution of the Bab Basin at the 
southern Neo-Tethys margin: response to global carbon-cycle perturbations across Ocean Anoxic Event 1a. Geophys Geochem Geosys 14:1 104-1130. https://doi.org/10.1002/ggge.20083

Zhang L, Orchard MJ, Algeo TJ, Chen ZQ, Lyu Z, Zhao L, Kaiho K, Ma B, Liu S

(2017) An intercalibrated Triassic conodont succession and carbonate carbon isotope profile, Kamura, Japan. Palaeogeogr Palaeoclimatol Palaeoecol. https://doi.org/10.1016/.jpalaeo.2017.09.001

\section{Publisher's Note}

Springer Nature remains neutral with regard to jurisdictional claims in published maps and institutional affiliations.

\section{Submit your manuscript to a SpringerOpen ${ }^{\odot}$ journal and benefit from:}

- Convenient online submission

- Rigorous peer review

- Open access: articles freely available online

- High visibility within the field

- Retaining the copyright to your article

Submit your next manuscript at $\boldsymbol{\nabla}$ springeropen.com 